\title{
Does working at a start-up pay off?
}

\author{
Daniel Fackler • Lisa Hölscher • Claus Schnabel (D) \\ Antje Weyh
}

Accepted: 6 May 2021 /Published online: 8 September 2021

(C) The Author(s) 2021

\begin{abstract}
Using representative linked employeremployee data for Germany, this paper analyzes short- and long-run differences in labor market performance of workers joining start-ups instead of incumbent firms. Applying entropy balancing and following individuals over ten years, we find huge and long-lasting drawbacks from entering a start-up in terms of wages, yearly income, and (un)employment. These disadvantages hold for all groups of workers and types of start-ups analyzed. Although our analysis of different subsequent career paths highlights important heterogeneities, it does not reveal any strategy through which workers joining start-ups can
\end{abstract}

D. Fackler

European Academy of Labour, University

of Frankfurt, Eschersheimer Landstraße 155-157, 60323 Frankfurt am Main, Germany

e-mail: fackler@eada.uni-frankfurt.de

L. Hölscher

Halle Institute for Economic Research (IWH), Kleine

Märkerstraße 8, 06108 Halle (Saale), Germany

e-mail: Lisa.Hoelscher@iwh-halle.de

C. Schnabel $(\bowtie)$

Department of Economics, University of Erlangen-

Nürnberg, Lange Gasse 20, 90403 Nürnberg, Germany

e-mail: Claus.Schnabel@fau.de

A. Weyh

Institute for Employment Research (IAB) Sachsen,

Glockenstraße 1, 09130 Chemnitz, Germany

e-mail: Antje.Weyh@iab.de catch up with the income of similar workers entering incumbent firms.

Plain English Summary Workers do not benefit from entering start-ups. This study analyzes a huge data set for Germany and compares similar workers who either join newly founded firms, so-called start-ups, or incumbent firms. It follows both groups of workers over ten years and finds substantial short- and long-run differences in their labor market performance. Entering a start-up instead of an incumbent firm is associated with huge drawbacks in terms of workers' wages, yearly income, and employment. These disadvantages exist for various types of workers analyzed and for different types of start-ups. There is no strategy through which workers who join start-ups can catch up with the income of comparable workers who enter mature firms. Thus, the practical implication of this study is that for most workers, it is advisable not to enter start-ups if they have a chance to obtain a decent job in a mature firm.

Keywords Start-ups · Young firms - Wages · Linked employer-employee data $\cdot$ Germany

JEL Classifications $\quad \mathrm{J} 31 \cdot \mathrm{J} 63 \cdot \mathrm{L} 26 \cdot \mathrm{M} 51$ 


\section{Introduction}

The role of newly founded firms, so-called start-ups, in structural change and job creation is a highly disputed topic both in scientific and political debates (Shane, 2009). There exists a broad empirical literature focusing on the quantity of jobs created and destroyed in new firms, across regions and at the aggregate level, mostly finding positive net effects of start-ups (see, e.g., Haltiwanger et al., 2013 for the USA, Fritsch \& Weyh, 2006 for Germany, Criscuolo et al., 2014 for 18 countries, and the review by Block et al., 2018). In contrast, relatively few studies have analyzed the quality of these jobs from the viewpoint of the individual worker. Some of these studies suggest that job quality in start-ups may be questionable, but evidence so far is too scarce to make any definite statements (see the reviews by Block et al., 2018 and Nyström, 2021). For workers-be they employed or unemployed-it is largely an open question whether joining a newly founded rather than an incumbent firm is advisable or not. Hence, the primary objective of this paper is to analyze empirically whether working at a start-up is beneficial in the short and long run for individual workers. Are there temporary or persistent advantages and disadvantages in terms of remuneration and (un)employment prospects from entering a start-up rather than an incumbent firm?

Although the quality of jobs is a multi-dimensional concept that also includes work content and non-monetary benefits (Block et al., 2018), the employment and earnings prospects individuals face in start-ups surely play a major role. Workers entering a start-up rather than an incumbent firm may receive higher wages as a compensation for the higher failure risk of start-ups, but they also could initially face lower wages due to the financial constraints of their young employer operating at an inefficient scale (Brixy et al., 2007). In the latter case, working at a start-up could pay off in the long run if new firms survive and become more profitable (Nyström, 2021). Wages in start-ups might even rise more steeply than in incumbent firms if flat hierarchies in expanding young firms mean that the initial workers are first in line to reach better-paid positions quickly (Fackler et al., 2019). Similarly, the greater variation in performed tasks and the expanded responsibility individuals typically experience in (small) start-ups may accelerate their career progression and earnings growth when moving to other, more mature firms. On the downside, the diverse and often idiosyncratic activities employees perform in start-ups may limit earnings growth and impede workers from moving to incumbent, betterpaying firms (Sorenson et al., 2021). Furthermore, wage profiles could be steeper in incumbent firms if these are more likely to offer backloaded compensation schemes to their employees-a strategy that will be less credible for risky new firms (Schmieder, 2013).

Regarding (un)employment prospects, workers in newly founded firms face a high risk of involuntary job loss due to their employer's closure (Fackler et al., 2013; Fairlie et al., 2019; Haltiwanger et al., 2013). Hence, entering a start-up might be associated with a higher risk of unemployment and worse future labor market opportunities due to displacement and stigma effects (Sorenson et al., 2021). As start-ups are particularly vulnerable to economic downturns, displaced employees of start-ups may experience more serious problems in finding a new job during a recession (Sorenson et al., 2021), and the resulting spells of unemployment may have negative, long-lasting effects on employment and earnings trajectories. Employees joining start-ups can thus be expected to record less days in employment and more days of benefit receipt (and consequently lower annual incomes). These brief considerations suggest that it is initially not clear whether entering a start-up as opposed to an incumbent firm will pay off for workers in the short and the long run.

In addressing this open question, previous research has primarily compared average wages in start-ups and incumbents or focused on differences in workers' entry wages at the point of being hired. The empirical evidence so far is ambiguous (see the reviews by Block et al., 2018 and Nyström, 2021). While some papers show that wages are significantly lower in start-ups than in incumbent firms, ceteris paribus (e.g., Fackler et al., 2019; Nyström \& Elvung, 2014), others find a positive wage differential, in particular for very successful start-ups (e.g., Ouimet \& Zarutskie, 2014; Schmieder, 2013). Brixy et al. (2007) identify a negative wage differential that becomes smaller over time, but they only have data at the 
level of establishments and not of workers. According to Burton et al. (2018), the typical start-up, which is both young and small, pays less than the average incumbent firm but the largest start-ups even pay a wage premium. Babina et al. (2019) report a pay penalty at young firms that turns into a small pay premium after controlling for various dimensions of worker and firm heterogeneity. Finally, Kim (2018) finds that MIT graduates at venture capital-backed start-ups (but not at other start-ups) earn about $10 \%$ higher entry wages than their counterparts at incumbent firms, which mainly reflects worker ability and selection.

Very few papers have been able to follow workers and their wages over time. ${ }^{1}$ The paper most closely related to our research is the study by Sorenson et al. (2021) with Danish registry data. Like us, the authors use a matched employer-employee database and follow (full-time) employees ten years after changing employers. They show that individuals who join young firms (i.e., less than four years old) earn substantially less than matched employees of large, mature firms over the subsequent ten years, and these earnings disparities are not found to diminish over time. Analyzing linked employer-employee data from Britain, Adrjan (2018) finds that young firms pay slightly higher wages to new hires, but subsequent wage growth is steeper at mature firms. He demonstrates that this finding holds both within continuing employment relationships and for individuals who change jobs, but he is not able to further analyze workers' (un)employment trajectories. A certain limitation of both studies is that they focus only on remuneration as the sole indicator for labor market success. In her recent review article, Nyström (2021, p. 928) concludes that "there is a clear scarcity of research regarding the long-term wage trajectories of employees in entrepreneurial firms." In addition,

\footnotetext{
${ }^{1}$ In their seminal work, where they find no robust and statistically significant wage differentials between workers in young and old firms, Brown and Medoff (2003) try to approach the long-term effects by controlling for tenure in their cross-sectional analysis. Babina et al. (2019) estimate earnings-tenure profiles for workers in young firms over the first three years and find evidence for flatter profiles in young firms when controlling for various dimensions of worker and firm heterogeneity.

2 A partial exception is the study by Schnabel et al. (2011) for Germany that compares the employment stability of one cohort of workers in newly founded and incumbent firms over a period of six years.
}

there is a lack of studies that look at the long-term (un)employment trajectories of individuals. ${ }^{2}$

Our paper contributes to this small literature and goes beyond previous studies in various ways. First, when asking whether it pays off to enter a start-up rather than an incumbent establishment, we not solely focus on wages but also consider other indicators of labor market success such as days in employment and unemployment benefit receipt. This is important because workers suffer from job loss and unemployment not only in terms of earnings losses but also in terms of non-monetary outcomes such as psychological costs or negative effects on children and families (see, e.g., the survey by Brand, 2015). Second, using a large, representative linked employer-employee data set for Germany, we follow individuals joining a start-up over ten years and analyze whether there are differences in wages and (un)employment compared to similar individuals who have entered incumbent firms. To ensure comparability of the two groups of workers, we apply entropy balancing (Hainmueller, 2012). We then examine whether the remaining differences are only temporary or long-lasting and whether they vary for different groups of workers. Third, we further add to the literature by investigating various potential explanations for the observed short- and long-term differences, such as joining successful vs. failing start-ups or pursuing different subsequent employment paths (like staying or leaving the establishment).

The upshot of our empirical analysis is that there are large and long-lasting drawbacks from entering a start-up rather than an incumbent establishment. Workers joining start-ups experience significantly lower income and daily wages, which is in line with recent studies on wage developments by Adrjan (2018) for Great Britain and Sorenson et al. (2021) for Denmark. In addition, we present first evidence that workers entering a newly founded firm record less days in employment and more days of benefit receipt than their counterparts joining incumbent firms. These disadvantages are persistent and hold for all groups of workers and types of start-ups analyzed.

The remainder of the paper is organized as follows: Section 2 explains our data and provides descriptive evidence on the composition of workers entering either a new or an incumbent firm. The methods and results of our econometric analyses are presented and discussed in Section 3. Section 4 concludes. 


\section{Data and descriptive evidence}

To analyze the different labor market prospects of workers entering either a start-up or an incumbent firm, we use an extensive linked employer-employee data set for Germany based on social security notifications, which is provided by the Institute for Employment Research (IAB). Our data set combines workerlevel information from the Integrated Employment Biographies (IEB) and establishment-level information from the Establishment History Panel (BHP).

Detailed data on labor market participants is collected in the IEB, which provides daily information on employment relationships for all workers subject to social security notifications, as well as periods of benefit receipt, registered job search, and participation in active labor market programs from 1975 to 2014 for Western Germany. ${ }^{3}$ Since 1992, Eastern Germany is included in the data as well, and from 1999 onwards, information on marginally employed workers is collected, too. Additionally, the IEB contains individual characteristics such as age, gender, education, and nationality. ${ }^{4}$

Yearly information on all German establishments with at least one worker subject to social security contributions is contained in the BHP, including size, sector, location, and workforce composition as of June 30 of a given year. ${ }^{5}$ Crucial for our analysis of newly founded establishments, the BHP also contains information on worker flows (Hethey-Maier \& Schmieder, 2013). In order to distinguish whether a new establishment identifier in the data refers to a truly new entry or is caused by mergers, acquisitions, or other changes of the identification number, worker flows are used to identify which fraction of a new establishment's initial workforce has previously been employed together in another establishment. We restrict our analysis to newly founded establishments defined by HetheyMaier and Schmieder (2013) as "new (small)" or "new (med \& big)", implying that the establishment either

\footnotetext{
3 This implies that the IEB only includes information on hired employees. The founders of the firms are not listed in the data, since they are not subject to social security contributions.

${ }^{4}$ For more information on the IEB, see Antoni et al. (2016) who provide a description of the Sample of the Integrated Labour Market Biographies (SIAB), a 2\% random sample from the IEB.

${ }^{5}$ For detailed information on the BHP, see Schmucker et al. (2016).
}

employs not more than three workers in its first year of business, or, if larger, less than $30 \%$ of its initial workforce have worked together under a common establishment identifier in the previous year.

Moreover, it must be noted that establishments in the BHP are defined as local production units, which do not necessarily correspond to firms as legal entities. Since we intend to focus our analysis on the foundation of new, independent firms instead of branch openings of multi-plant firms, we exclude establishments with more than 20 employees in their first year of business. We evaluate the success of this procedure in reducing the number of branch openings by using information from the IAB Establishment Panel, a yearly survey of approximately 16,000 German establishments. ${ }^{6}$ Since the Establishment Panel includes information on single- and multi-plant firms, we can link this information with those establishments from the BHP that we classify as start-ups as described above and that meet further sample restrictions described below. It can be shown that circa $94 \%$ of the establishments we define as start-ups are independent new firms, while only $6 \%$ are branch openings of existing entities.

The sample of start-ups that is used for our analyses consists of a $10 \%$ random draw of all establishments newly founded in the years 2000 to 2004, only focusing on establishments in their very first year of business. We then link information from the IEB on all newly hired workers in the respective year, i.e., workers that have not been working with the same employer in the previous year. Since workers' employment biographies are available until 2014, this allows us to follow each cohort of workers (and firms) over ten subsequent years. Note that we do not restrict our analysis to a balanced panel but allow for attrition, e.g., due to exit from the labor force. The control group of incumbent establishments is constructed by drawing a 5\% sample of all establishments existing during that period. Here, for each cohort of workers, we keep only those

\footnotetext{
${ }^{6}$ For further information on the IAB Establishment Panel see Ellguth et al. (2014). We do not use the IAB Establishment Panel in our main analysis, even though it includes some additional information at the firm level, because the number of young establishments in the data set is rather small and typically establishments in their very first year of existence are not included in the survey at all.
} 
Table 1 Selected characteristics of new and incumbent establishments (means)

\begin{tabular}{lcl}
\hline Variable & New establishment & Incumbent \\
\hline Number of employees & $2.64(2.67)$ & $31.20(293.61)^{* * *}$ \\
Secondary sector $(\%)$ & $20.35(40.26)$ & $32.63(46.89)^{* * *}$ \\
Tertiary sector (\%) & $79.65(40.26)$ & $67.37(46.89)^{* * *}$ \\
Share of women (\%) & $47.64(43.52)$ & $50.60(33.40)^{* * *}$ \\
Share of full-time workers (\%) & $68.89(38.14)$ & $60.50(30.64)^{* * *}$ \\
Share of marginally employed workers $(\%)$ & $15.43(25.31)$ & $22.66(26.62)^{* * *}$ \\
Number of observations & 53,666 & 126,998 \\
\hline
\end{tabular}

Sources: Establishment History Panel (BHP); authors' calculations. Notes: Sample includes only establishments in the years 20002004, excluding agriculture, energy and mining, and the public and nonprofit sectors. Standard deviations are reported in parentheses. *, **, and *** indicate statistically significant differences between the two groups at the 10,5 , and $1 \%$ level, respectively

who join establishments that are five years or older. ${ }^{7}$ In both groups, we exclude establishments in agriculture, energy and mining, and in the public sector. We further exclude workers younger than 18 and older than 50 at the time of being hired, as well as apprentices.

Table 1 gives a short overview over the establishments in our final sample. To summarize the composition of workers entering new and incumbent establishments, respectively, we present selected individual characteristics at the point of entry in Table 2 . We see that the two groups differ significantly in almost all variables presented. Workers entering new establishments are more often women and they are on average older than the control group. They are more often mediumqualified, while a higher share of workers entering incumbent establishments is either low-qualified, i.e., having no degree at all, or high-qualified, i.e., graduated from university. Moreover, workers taking up a job in a start-up are less often of German nationality, have less frequently performed a job-to-job transition ${ }^{8}$ and are less often hired in a part-time job. In terms of years of working experience, we find no significant

\footnotetext{
7 The threshold of five years might appear arbitrary, but Brixy et al. (2006) show that after the first five years of business, differences in wage levels and working conditions between new and incumbent firms become insignificant.

${ }^{8}$ Following Fackler et al. (2019), we define job-to-job transitions as recruitments where individuals left their previous job not more than 90 days before joining the respective establishment, hence allowing for a short period of frictional unemployment. If workers left their previous job more than 90 days ago and in the meantime were registered as a job seeker, received benefit payments, participated in labor market programs or were not observed in the data, they are not defined as transitioning from employment.
}

differences, while workers entering new establishments have previously spent more time in benefit receipt. ${ }^{9}$ Moreover, individuals entering start-ups have had more previous employers, which points towards more stable employment biographies in the control group. All these differences in the sample composition might affect the labor market success of the two groups of workers. Our goal in the following empirical analysis is to study workers' employment trajectories in the long run and to investigate whether various indicators of labor market success differ between workers entering either a start-up or an incumbent, thereby conditioning a broad range of individual and firm characteristics.

\section{Empirical analysis}

\subsection{Econometric approach}

To account for differences in the composition of the groups of workers entering start-ups vis-à-vis incumbents, we apply entropy balancing (Hainmueller, 2012, see Hainmueller \& Xu, 2013 for a description of the respective Stata ado-file ebalance). This method allows us to directly impose the first and second moments, i.e., means and variances, of a large set of covariates to be perfectly balanced among both groups. Without having to postulate any further assumptions, entropy balancing reweights observations to match the

\footnotetext{
9 Note that working experience and benefit receipt are truncated at eight years because eastern German workers only joined the data in 1992. Hence, for the cohort of workers hired in 2000 we can only observe eight years of their employment histories.
} 
Table 2 Selected characteristics of workers entering either a new or an incumbent establishment (means)

\begin{tabular}{lcc}
\hline Variable & New establishment & Incumbent \\
\hline Women (\%) & $47.66(49.95)$ & $46.59(49.88)^{* * *}$ \\
Age: $18-24$ years (\%) & $19.21(39.39)$ & $22.84(41.98)^{* * *}$ \\
Age: $25-34$ years (\%) & $35.23(47.77)$ & $36.57(48.16)^{* * *}$ \\
Age: $35-50$ years (\%) & $45.56(49.80)$ & $40.59(49.11)^{* * *}$ \\
Low-qualified (\%) & $14.88(35.59)$ & $15.87(36.54)^{* * *}$ \\
Medium-qualified (\%) & $77.85(41.52)$ & $72.91(44.44)^{* * *}$ \\
High-qualified (\%) & $7.27(25.96)$ & $11.22(31.56)^{* * *}$ \\
Foreign nationality (\%) & $12.61(33.20)$ & $11.33(31.70)^{* * *}$ \\
Transition from employment $(\%)$ & $55.89(49.65)$ & $56.96(49.51)^{* * *}$ \\
Part-time (\%) & $28.62(45.20)$ & $29.06(45.40)^{* * *}$ \\
Years of work experience & $5.20(2.84)$ & $5.21(2.93)$ \\
Years of benefit receipt & $1.15(1.69)$ & $0.82(1.45)^{* * *}$ \\
Number of previous employers & $4.58(3.84)$ & $3.97(3.60)^{* * *}$ \\
Number of observations & 110,201 & 614,838 \\
\hline
\end{tabular}

Sources: Integrated Employment Biographies (IEB); Establishment History Panel (BHP); authors' calculations. Notes: Sample includes only workers entering establishments in the years 2000-2004, excluding agriculture, energy and mining, and the public and nonprofit sectors. Only individuals of age 18-50 are comprised, excluding apprentices. Years of work experience and years of benefit receipt are truncated at 8 years. Standard deviations are reported in parentheses. *, **, and *** indicate statistically significant differences between the two groups at the 10,5 , and $1 \%$ level, respectively

respective balance constraints by deviating as little as possible from the initial weights. By directly focusing on covariate balance, entropy balancing improves on related methods such as propensity score matching, which often depend on manual adjustment of the weighting scheme and repetitive balance checking and therefore frequently fail to balance all covariates perfectly. Moreover, while matching approaches often discard less comparable individuals in the control group, entropy balancing retains all relevant information by assigning weights smoothly to all observations in the data (Hainmueller \& Xu, 2013). ${ }^{10}$ In our case, we aim to compare two groups of individuals with the same preconditions when joining an establishment, so that diverging trajectories in labor market performance in the subsequent years can be more credibly ascribed to entering either a new or an incumbent establishment. Thus, we balance the two groups of workers

\footnotetext{
10 To check whether our results depend on the empirical method chosen, we additionally run a robustness test where we substitute entropy balancing with propensity score matching. Moreover, we estimate an unweighted OLS regression in which we control for all explanatory variables that are also used in our balancing procedure. Results are almost identical to the main outcomes discussed below and are available upon request.
}

among a wide range of characteristics at the point of entering a start-up or an incumbent, respectively, and compare the subsequent career paths of the reweighted groups for the ten following years.

More specifically, we require observations in the control group to be reweighted so that means and variances of the workers' year of entry, sex, age, qualification and German nationality equal those of the group of workers entering a start-up, since all these characteristics typically account for differences in individual career paths and wages. ${ }^{11} \mathrm{We}$ also balance the two groups in terms of preceding employment status, indicating whether an individual either has performed a job-to-job transition or has come from unemployment or outside the labor market, and in terms of total previous years of experience and years

\footnotetext{
11 While it would be technically possible to balance further moments of the variables' distribution, we act in accordance with Hainmueller (2012, p. 32) who states that "in many empirical cases we would expect the bulk of the confounding to depend on the first and second moments." As a technical side note, introducing skewness into the procedure does not change the balancing of most of our variables since they are coded as dummy variables.
} 
of benefit receipt. In addition to these variables that might affect workers' labor market opportunities, we include the number of former employers in the balancing procedure to capture previous employment stability. Moreover, we also impose the two groups to be balanced concerning the new job's part-time status and occupation, as well as the (two-digit level) sector and labor market region of the establishment. ${ }^{12}$ We do not include establishment size in our balancing procedure because comparing small start-ups with similarly small incumbents may be misleading. According to learnings models such as Jovanovic (1982), new firms start at a small scale because they do not know their true efficiency. Firms that are more efficient will grow and survive whereas less efficient firms shrink and eventually exit the market. Hence, comparing start-ups and incumbents with the same size implies a comparison between young (and potentially efficient) firms unaware of their optimal employment level with inefficient incumbent firms that have not grown or are even shrinking. Nevertheless, we also perform a robustness check making start-ups and incumbents more comparable in size, which is discussed in Section 3.3.

We investigate individuals' labor market performance over time in terms of yearly income, ${ }^{13}$ average daily full-time earnings, ${ }^{14}$ days in employment, and days of benefit receipt ${ }^{15}$ in the reweighted sample for the next ten years following workers' entry in the respective establishment. To compare these indicators

\footnotetext{
12 We categorize occupations according to Blossfeld (1987). Labor market regions are classified on the basis of workers' commuting patterns according to Kropp and Schwengler (2011).

13 Our income measure cumulates daily wages from all employment relationships of a given year and is deflated by the consumer price index. If an individual holds multiple simultaneous employment relationships, only the main (i.e., the highest paying) job is taken into account.

14 Note that our indicator for wages, average daily earnings, is defined conditional on full-time employment. Since our data does not contain information on working hours, we are not able to calculate hourly wages. Hence, part-time workers are excluded from the analysis of wages to reduce heterogeneities in working hours. Wages are deflated by the consumer price index.

15 Benefit receipt refers to unemployment insurance benefits (Arbeitslosengeld I) and means-tested social assistance (Arbeitslosengeld II).
}

between the two groups of workers, we run an OLS regression in the balanced sample,

$Y_{i t}=\sum_{t} \beta_{t} T_{t}+\sum_{t} \gamma_{t} S U_{i} T_{t}+v_{i t}$

where $Y_{i t}$ determines the labor market outcome of interest for individual $i$ in year $t$ and $T$ indicates a set of relative time dummies, ranging from zero in the year in which the individual newly enters the establishment up to year 10. Additionally, these time dummies interact with a start-up indicator $S U_{i}$ that is equal to one if the worker had entered a new establishment and zero for workers who had joined an incumbent firm at the beginning of the observation period. The coefficient $\gamma_{t}$ therefore shows the difference in the performance of the two balanced groups of workers for each year.

Our empirical approach allows us to render the two groups of workers comparable among a broad set of observable characteristics. However, it must be acknowledged that there may be further dissimilarities between the individuals which we are not able to capture with our identification strategy, but which could affect their future career paths as well. For example, workers entering start-ups might be less risk averse than workers who choose to work for an incumbent (Kim, 2018). One might also imagine workers joining new firms to have a stronger preference for non-monetary aspects of a job, such as flat hierarchies, more independence and responsibility or more diverse tasks which are often associated with working at a start-up (Sauermann, 2018; Sorenson et al., 2021). These characteristics may also play a role in workers' future career decisions and affect their success in terms of wages and employment.

Since these (and other) unobservable differences could bias our estimate of differences in labor market performance, we additionally apply a robustness check in which we include workers' labor market outcomes of the three preceding years in our balancing procedure. By controlling for income, as well as days in employment, full-time employment, and benefit receipt, of the three years prior to entering the establishment, we abstract from any unobservable differences between the two groups of workers that had affected their labor market trajectories before our 

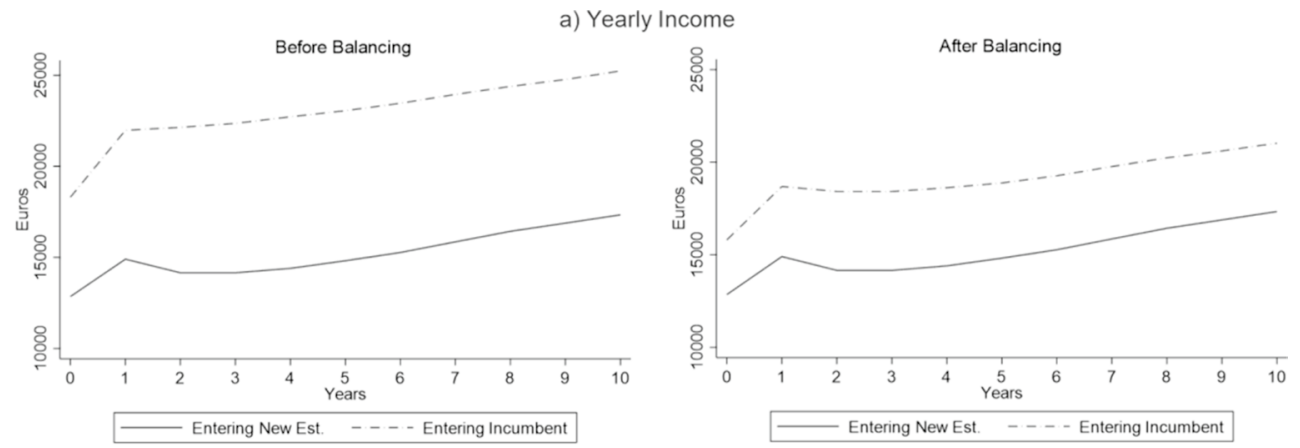

b) Average Daily Full-Time Earnings
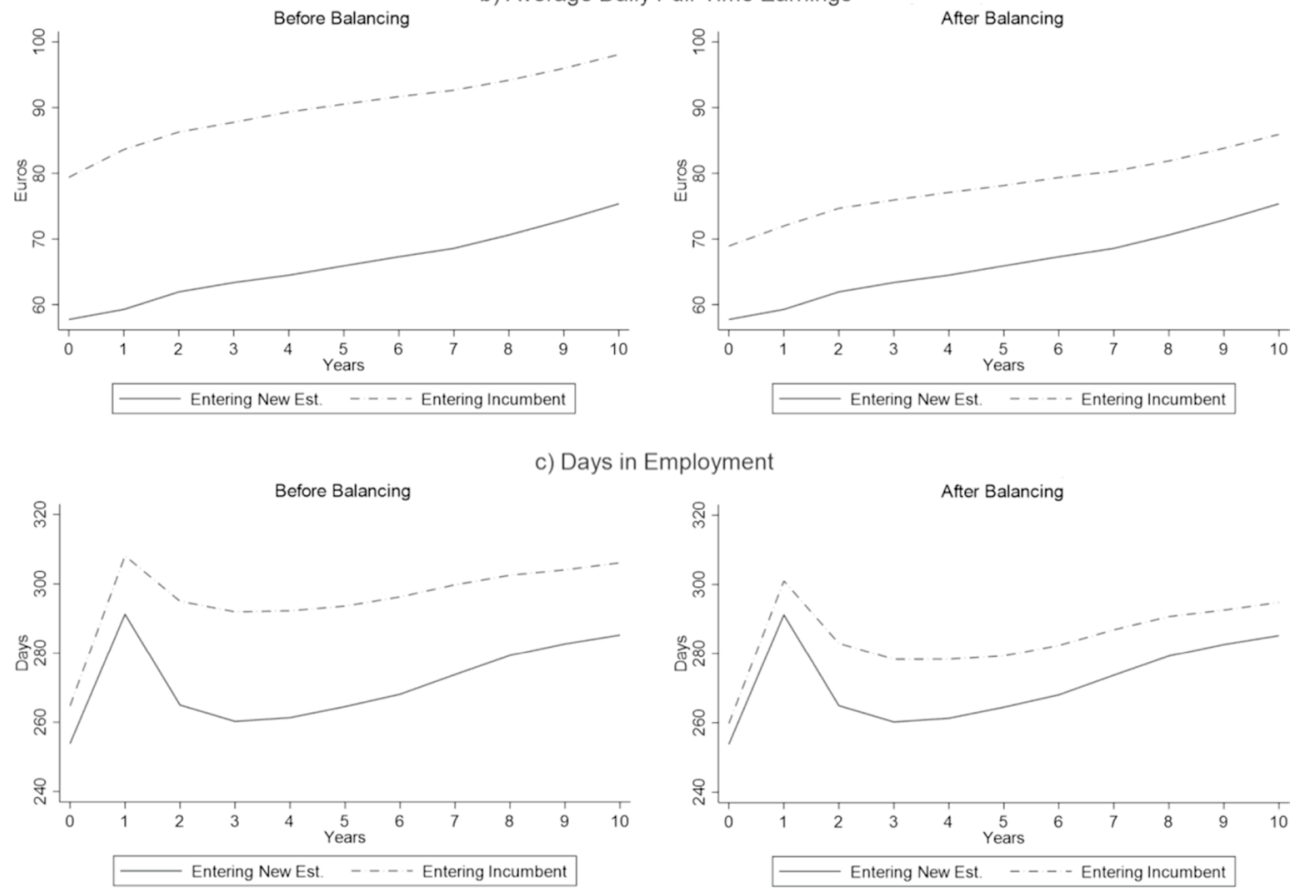

d) Days of Benefit Receipt
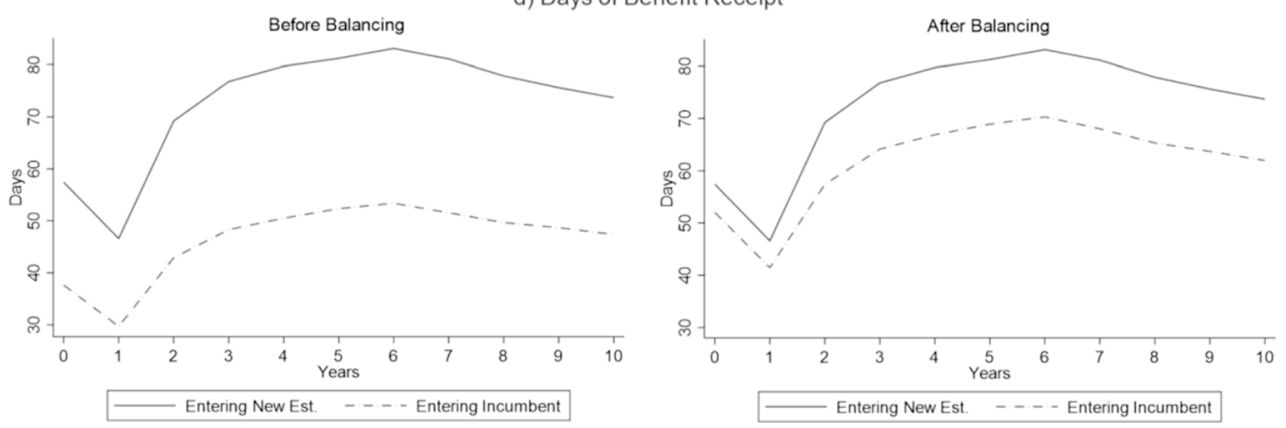

Fig. 1 a-d Labor market trajectories of workers entering new and incumbent establishments, before and after entropy balancing. Sources: Integrated Employment Biographies (IEB); Establishment History Panel (BHP); authors' calculations.

Notes: Sample includes only workers entering establishments in the years 2000-2004, excluding agriculture, energy and mining, and the public and nonprofit sectors. The sample comprises individuals of age 18-50, excluding apprentices 
observation period. ${ }^{16}$ Results of this robustness test will also be discussed in the following. However, we do not control for labor market outcomes in preceding years in our main analysis since introducing the additional variables into entropy balancing would force us to discard all labor market entrants from our sample.

\subsection{Results}

The labor market trajectories of workers entering either a start-up or an incumbent establishment, both before and after entropy balancing, are presented in Fig. 1. A first look already reveals that workers who joined a start-up in year zero perform worse in terms of all outcome variables over the whole observation period. Even though entropy balancing strongly reduces the gap between the two groups of workers, pointing towards negative selection into start-ups, the overall patterns remain stable.

Taking a closer look at each labor market outcome, one can see that workers entering a start-up already have lower yearly incomes in the year of entry, even after balancing. ${ }^{17}$ This gap seems to widen slightly in the first years and then remains very persistent, without any indication that workers who initially entered a new establishment catch up to the control group. It should be noted that our indicator for yearly income captures two aspects, an employed worker's wage and (periods of) non-employment in the respective year, the latter being assigned zero earnings. We therefore disentangle the two aspects by looking separately at wages (conditional on full-time employment) and days in employment. Focusing on average daily full-time earnings first, Fig. 1b shows lower wages for workers in start-ups already in year zero, and the difference to the balanced group of workers entering incumbents hardly changes during the ten subsequent years. In terms of days in employment as well as days of benefit receipt, there is more variation over time. While differences in the year

\footnotetext{
16 We do not control for average daily full-time wages (conditional on full-time employment) because we would have to discard all individuals who spent one or more of the three preceding years in part-time employment or non-employment.

17 This finding is consistent with the study by Fackler et al. (2019), reporting that individuals receive lower entry wages when joining start-ups, ceteris paribus.
}

of entry are comparably small, the gap between the two groups widens considerably in the following two years, potentially picking up the effect of higher failure rates among start-ups. There seems to be some convergence in terms of days in employment, but workers who initially entered a start-up still perform worse than the control group even after ten years. ${ }^{18}$

In order to assess the differences in labor market performance and their statistical significance, Fig. 2 shows the estimation results of the OLS regression described above. More specifically, the lines indicate the magnitude of the coefficients $\gamma_{t}$ and the respective $95 \%$ confidence intervals for estimations in the unbalanced and the balanced sample. Our results confirm that workers entering a start-up perform significantly worse than the control group over the subsequent 10 years. Even after entropy balancing, they earn about $€ 4000$ (or approximately 20\%) less yearly income from the second year onwards compared to workers who joined an incumbent firm, and this gap remains stable until the end of our observation period. Two factors contribute to this difference in yearly income: one is the persistently lower wages of approximately $€ 10$ (roughly 15\%) less per day ${ }^{19}$ and the other is the continuously lower probability of being employed. After two years, workers in a new establishment spend almost 20 days less in employment per year than their peers in incumbents, and while this gap is slightly reduced over the next years, differences remain highly significant throughout the observation period. The fact that there is also a strong increase in days of benefit receipt compared to the control group over the first two years after entry suggests that these workers usually do not have other income sources compensating employment losses.

As discussed above, one might be skeptical whether our empirical approach is successful in reducing all differences between the two groups of workers, since in entropy balancing, we

\footnotetext{
18 That Fig. 1 shows less convergence in benefit receipt than in employment might reflect that the first measure also comprises workers who are back in employment, but whose wages are so low that they receive additional benefit payments.

19 This significant and persistent gap can also be found when looking at log wages.
} 
a) Differences in Yearly Income (OLS)

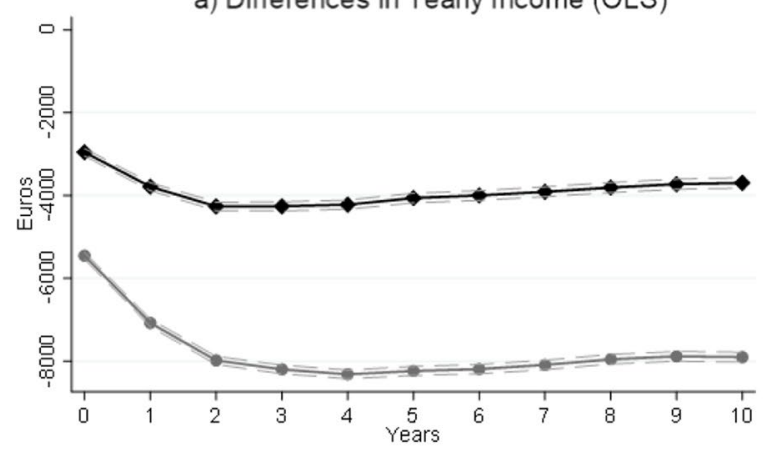

c) Differences in Days in Employment (OLS)

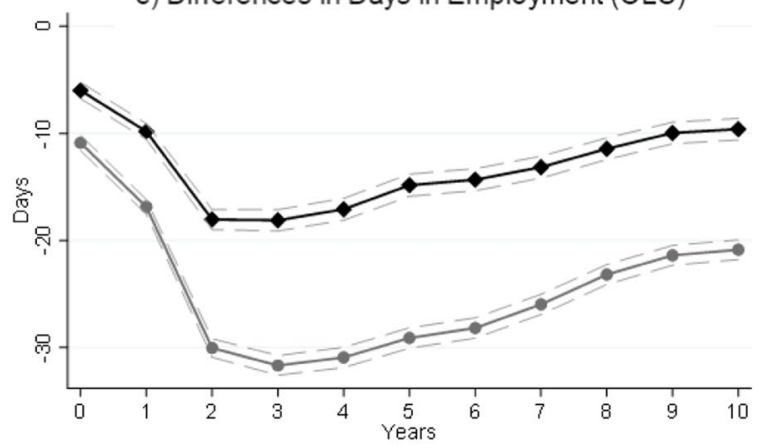

b) Differences in Av. Daily Full-Time Earnings (OLS)

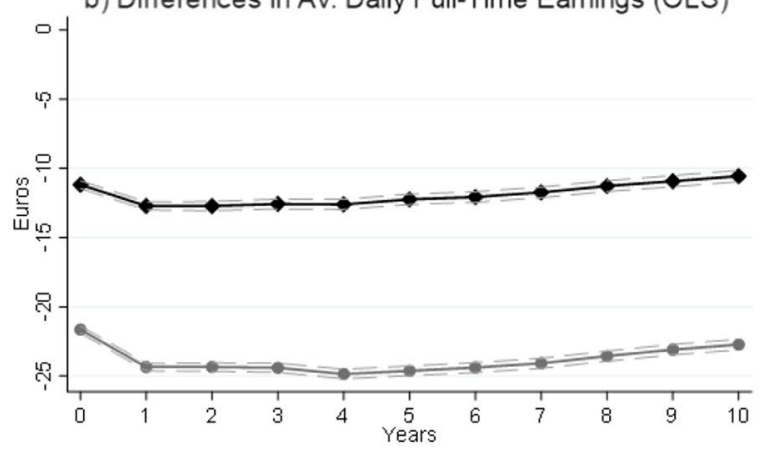

d) Differences in Days of Benefit Receipt (OLS)

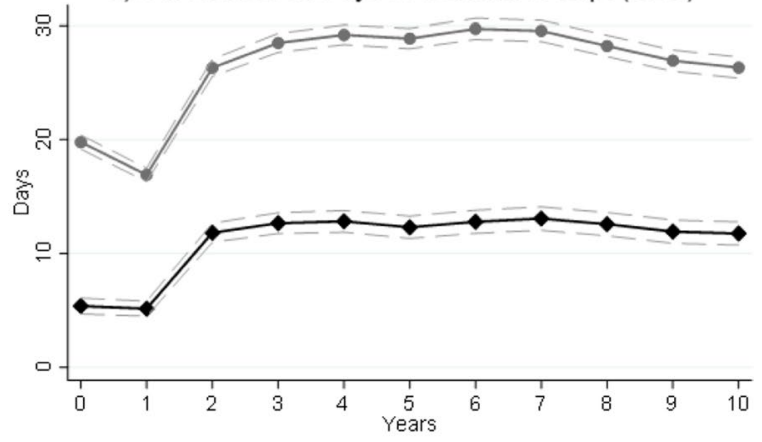

Fig. 2 a-d OLS estimates of differences in labor market trajectories between workers entering new and incumbent establishments, before and after entropy balancing. Sources: Integrated Employment Biographies (IEB); Establishment History Panel (BHP); authors' calculations. Notes: Sample includes only workers entering establishments in the years 2000-2004,

cannot control for unobservable characteristics such as ambition or risk aversion. In Fig. 5 in the Appendix, we therefore present the results of a robustness check in which we include indicators of labor market performance in the three preceding years in the balancing procedure as crude proxies of unobserved characteristics. Here, we assume that workers' behavior resulting in a worse labor market performance (such as many days of benefit receipt) does at least partially reflect workers' ambition, risk aversion, or other unobservable characteristics. It can be shown that although there are no remaining differences in terms of labor market success in the years -3 to -1 after reweighting the two groups, there are still substantial differences in labor market performance after entering the respective establishment, thus excluding agriculture, energy and mining, and the public and nonprofit sectors. Sample comprises individuals of age 18-50, excluding apprentices. Graphs show the OLS estimates of differences in labor market trajectories as listed in Table 3 and 4 in the Appendix; the gray dashed lines indicate the $95 \%$ confidence intervals

confirming the findings of our main specification. ${ }^{20}$ These differences remain even if we include worker fixed effects. ${ }^{21}$ Additionally, we use workers' previous employment histories to generate further proxies

\footnotetext{
${ }^{20}$ Note that for this robustness test, we have to exclude all individuals with missing information on labor market performance for one or more of the three preceding years. To test whether this smaller sample differs strongly from our main sample in terms of subsequent labor market performance, we rerun the original balancing procedure (without controlling for previous labor market success) in this subsample and find that results are in line with our main results.

${ }^{21}$ Including fixed effects in our regression only takes account of level-differences between workers, not of developments. Thus, any interpretation hinges strongly on the chosen reference year and is not easily comparable to our main results. We therefore do not include fixed effects in our preferred specification. However, results are available on request.
} 
for unobservable preferences, namely the number of occupations (on the three-digit level) before entering the establishment, the number of start-ups an individual previously worked for, and a dummy indicating whether the last employer was a young establishment not older than five years. While including these variables in the balancing procedure does not change our insights, it reduces our sample considerably, especially by those individuals who have just entered the labor market. Therefore, we do not include these measures in our main specification.

Moreover, we estimate an additional robustness check where we restrict our analysis to workers who enter an establishment with a maximum of 20 employees, to make both groups more comparable with respect to establishment size. In our preferred specification, we do not control for establishment size, since comparing small start-ups only to a group of similarly small incumbents may be misleading. While a small start-up might grow quickly in its first years of business, an established firm of comparable size potentially signals that it has been not so successful so far and therefore did not expand. Therefore, our main insights might also be driven by differences in establishment size coming along with establishment age. The results of this robustness check (Fig. 6 in the Appendix) show that even after making the two groups more comparable in terms of establishment size, we still find significant and persistent drawbacks from joining a start-up. While the differences in earnings shrink by more than half compared to the results of our preferred specification, differences in terms of employment prospects are similar in size. ${ }^{22}$

To sum up, our main results imply that workers entering a start-up suffer from severe and long-lasting drawbacks in terms of earnings and employment prospects, compared to workers joining an incumbent establishment

\footnotetext{
22 A potential explanation for this finding is that firm age is a more important determinant of employment stability than firm size. That our results are broadly similar when comparing days in employment or benefit receipt—both variables being proxies of employment stability-between start-ups and incumbents of similar size implies that firm size is not an important determinant of employment stability. Hence, the difference between workers entering start-ups and incumbents is largely driven by firm age (rather than size). Size, however, turns out to be an important determinant of wages or earnings, which is in line with previous studies on the relationship between firm size and wages.
}

instead. To analyze whether these insights hold for various subgroups of workers, we perform entropy balancing separately for subgroups defined by gender, age, qualification, and previous employment status, and run OLS regressions for each of these balanced subsamples. We further investigate whether our insights also apply to different percentiles of the income distribution. The respective regression results for yearly income as a summary measure for wages and employment prospects are provided in Fig. 3.

With respect to gender, the income penalty of workers entering start-ups rather than incumbents is slightly larger for men than for women. In year zero, for instance, the difference amounts to $€ 3400$ for men and to $€ 2000$ for women, which corresponds to percentage income gaps of 18 and $16 \%$, respectively. The development of the income gap over the subsequent ten years is remarkably similar for both sexes. Focusing on subgroups defined by age, the youngest workers are experiencing the smallest (but still significant) drawbacks from joining a new establishment, as differences to the balanced control group amount to approximately $€ 2000$ in all years of observation. The income difference increases with workers' age group, both in absolute and relative terms, indicating that the decision to enter a start-up is most harmful for old workers. One potential explanation for this pattern is that when entering incumbent firms, older workers can make better use of the human capital they have accumulated during their working life. This is supported by the finding that the income difference between young and old workers is largely driven by wages rather than employment.

Analyzing the development of yearly income for workers of different qualification, we find that the difference to the control group is the largest for workers with a university degree, who earn almost $€ 6000$ less even ten years after entry. ${ }^{23} \mathrm{~A}$ similar pattern emerges when we investigate income trajectories for different percentiles of the income distribution. Here, instead of estimating OLS regressions, we estimate unconditional quantile regressions using recentered influence functions (RIFs) as proposed by Firpo et al. (2009). We focus on the 20th, 50th, and 80th percentile to study the impact of joining a start-up on low-income

\footnotetext{
23 The percentage income gap, however, is largest for mediumqualified workers in most periods.
} 
a) By Gender (OLS)

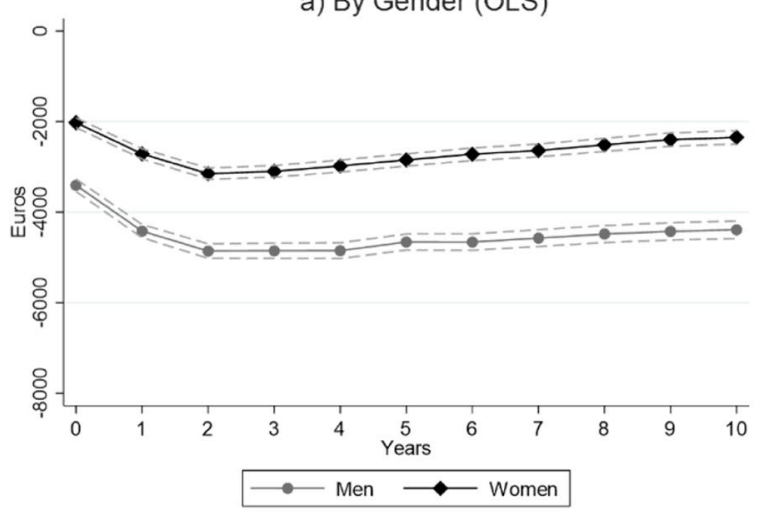

c) By Qualification (OLS)

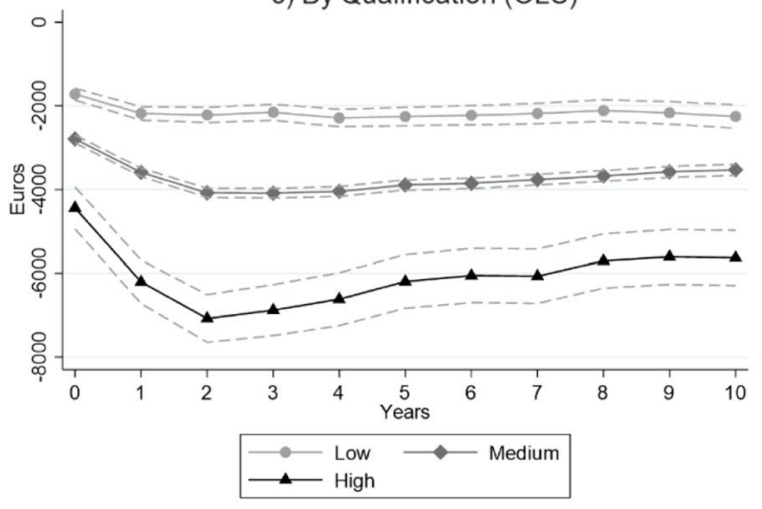

b) By Age (OLS)

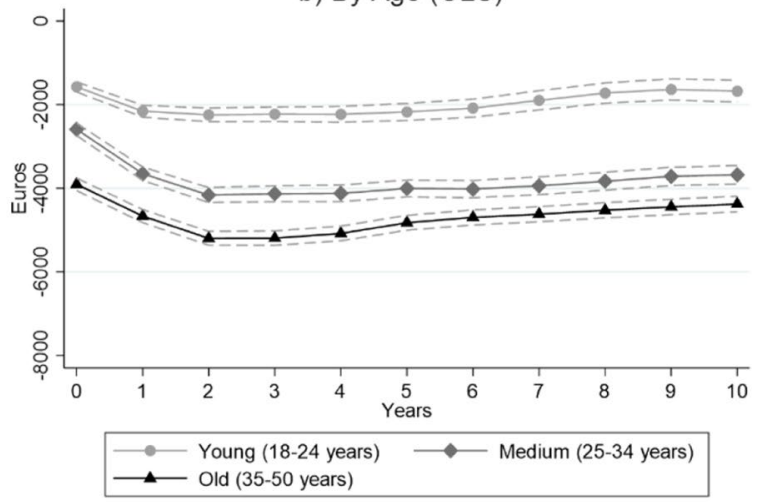

d) By Income Percentile (RIF)

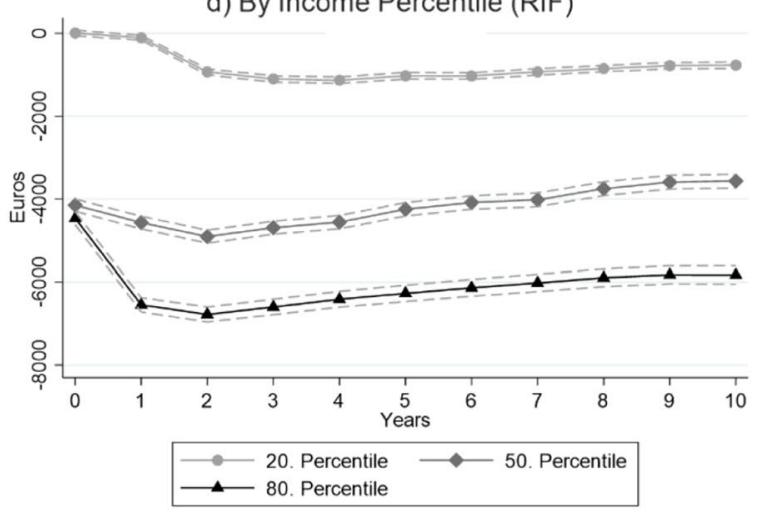

e) By Prev. Employment Status (OLS)

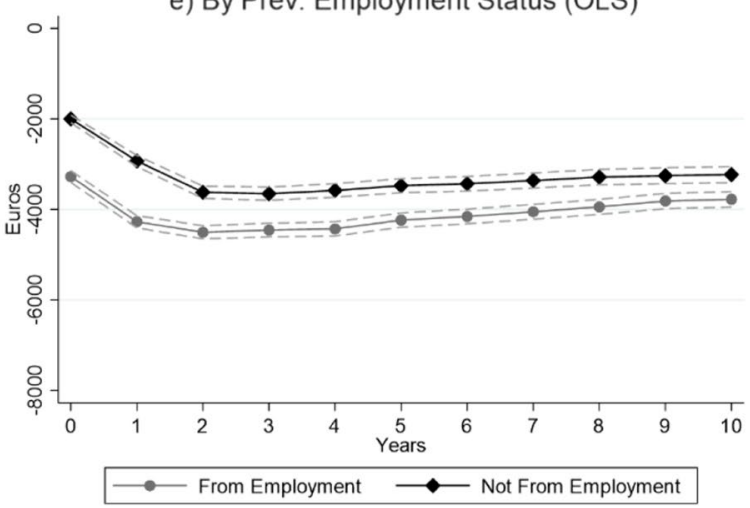

Fig. 3 a-e Subgroup regression estimates (OLS and RIF) of differences in yearly income between workers entering new and incumbent establishments after entropy balancing. Sources: Integrated Employment Biographies (IEB); Establishment History Panel (BHP); authors' calculations. Notes: Sample includes only workers entering establishments in the years
2000-2004, excluding agriculture, energy and mining, and the public and nonprofit sectors. The sample comprises individuals of age 18-50, excluding apprentices. Graphs show the OLS (and RIF) estimates of differences in labor market trajectories; the gray dashed lines indicate the $95 \%$ confidence intervals 
and high-income earners as well as on the median. ${ }^{24}$ Results show that entering a newly founded establishment decreases income most for workers at the 80th percentile of the distribution, while the 20th percentile is affected to a much smaller extent, indicating that especially workers with high income suffer severe drawbacks (in absolute terms) from joining a start-up as opposed to an incumbent. ${ }^{25}$ Note that, for a closer look at high-wage workers, we run an additional analysis of those individuals who are in the highest $20 \%$ of the overall income distribution in the initial year of joining the start-up and, alternatively, in the year before. Comparing high-wage workers in start-ups with high-wage workers in incumbents confirms the results of our main regression.

Finally, we also test whether the consequences of entering a start-up vary for workers with different previous employment statuses and find that the difference to the control group is slightly larger for workers who performed a job-to-job transition compared to those who came from non-employment. The percentage income gaps, in contrast, are somewhat larger for workers coming from non-employment due to their overall lower income levels. Nevertheless, developments over time are very similar for both groups. In conclusion, even though the disadvantages from entering a start-up as opposed to an incumbent are most pronounced for men, old employees, and highly qualified employees, as well as for workers in the upper part of the income distribution, we find that all subgroups earn lower incomes when joining start-ups rather than incumbents over the whole period of observation.

\subsection{Results for different subsequent career paths}

To explore potential explanations for the significant and long-lasting difference in performance between

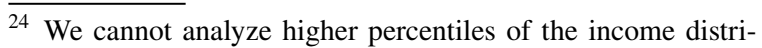
bution, since information on earnings is censored at the contribution limit for social security contributions, which affects approximately $18 \%$ of observations in our sample. Note that as more high-wage workers are found among those entering incumbents, this should, if anything, lead to an underestimation of the difference between the two groups of workers in our main analysis.

25 In relative terms, income gaps are largest at the median at the beginning of the observation period and at the 20th percentile in later years.
}

workers entering start-ups and those joining incumbents, we also investigate income trajectories for workers with different specific subsequent career paths. Specifically, we have a closer look at workers who stay with their initial employer to check whether worse labor market prospects in start-ups occur (only) due to their lower employment stability compared to incumbents. Moreover, to shed light on the relevance of the high failure risk of start-ups for workers' labor market performance, we compare workers who join a start-up that turns out to be successful and does not close down in the early years of business with those entering businesses that subsequently fail. We further examine the role of startups as "stepping stones" to other positions in workers' subsequent careers. Figure 4 shows the results of these analyses for yearly income.

Focusing on continuing matches, we include only those workers who are still employed with the same establishment which they entered in year zero. Comparing income trajectories of stayers in start-ups with those of stayers in incumbent establishments after balancing (Fig. 4a), we see that the difference between the two groups is even more pronounced than in our main analysis, and the gap widens continuously over the observation period. This result indicates that the lower employment stability in start-ups cannot be the only reason for the differences in labor market performance described above. We also find no indication that those workers who remain employed in a start-up over a longer period of time are experiencing steep careers and better earnings prospects (e.g., due to flat hierarchies in newly founded establishments). Instead, continued employment in incumbents seems to lead to steeper wage increases, e.g., due to backloaded compensation schemes or better opportunities for career advancement in internal labor markets. ${ }^{26}$ Moreover, we analyze subgroups of workers with

\footnotetext{
${ }^{26}$ The widening of the income gap between the two groups might also be a result of selective attrition over time, if, for instance, only especially capable workers stay with incumbents, while only the least qualified continue to work for a start-up. To check whether such selection processes drive our results, we compare the characteristics of individuals who remain with their initial employer over time and find no indication for differences in selection dynamics over time for workers in start-ups and incumbents. Additionally, we employ entropy balancing for each period separately, to ensure that the two groups are balanced in each year, and then rerun our OLS estimation with these time-varying weights. Our insights remain unchanged.
} 


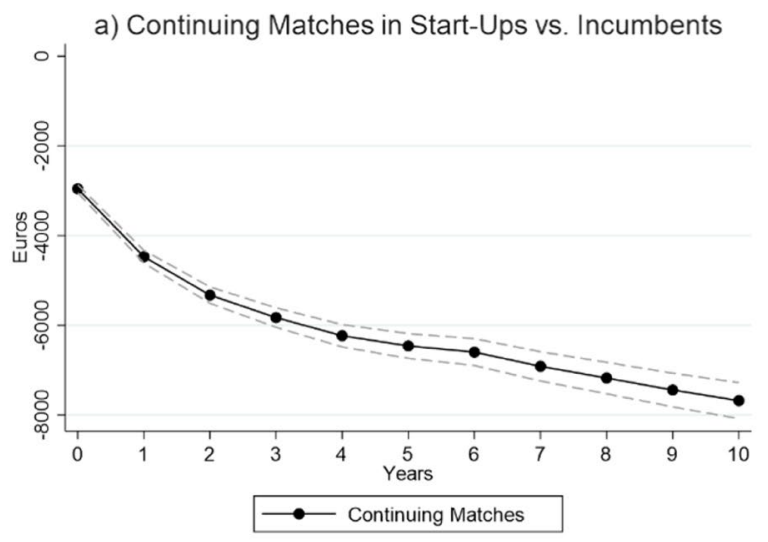

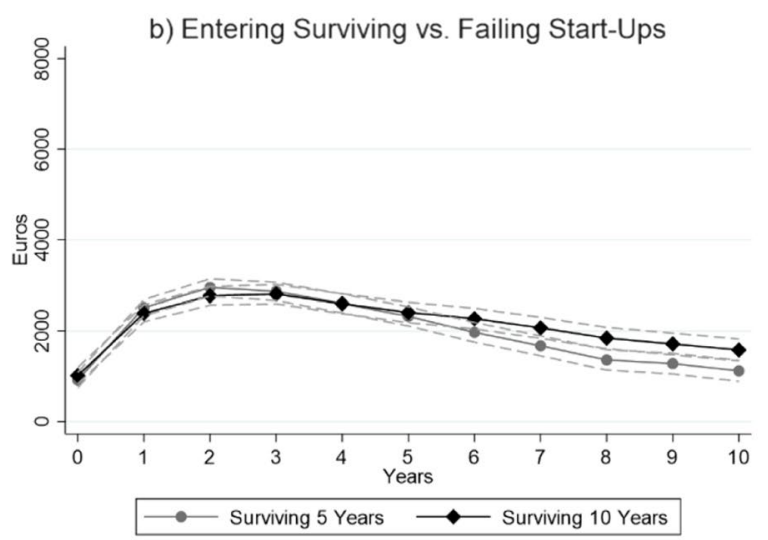

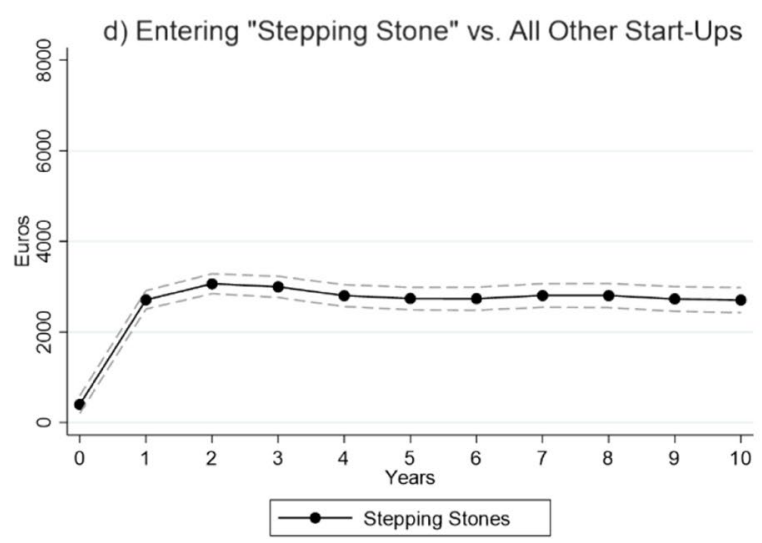

Fig. 4 a-e OLS estimates of differences in yearly income for workers with different subsequent career paths after entropy balancing. Sources: Integrated Employment Biographies (IEB); Establishment History Panel (BHP); authors' calculations. Notes: Sample includes only workers entering establishments in the years 2000-2004, excluding agriculture, energy

different lengths of start-up employment (results are available on request). For individuals who leave the start-up in the first year or between years 2 and 5, we

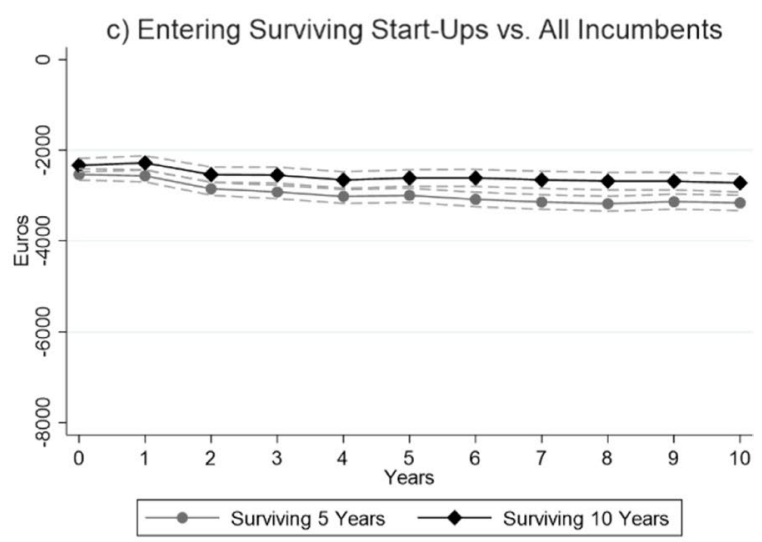

e) Entering "Stepping Stone" vs. All Incumbents

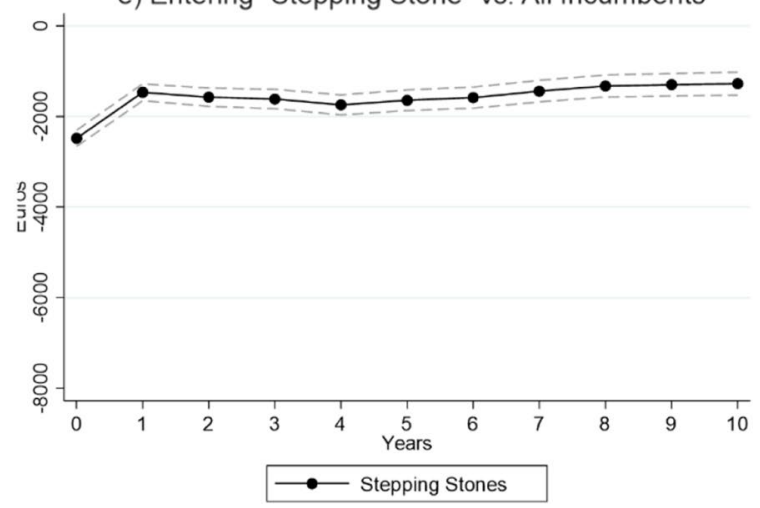

and mining, and the public and nonprofit sectors. The sample comprises individuals of age 18-50, excluding apprentices. Graphs show the OLS estimates of differences in labor market trajectories; the gray dashed lines indicate the $95 \%$ confidence intervals

find a sharp drop in days in employment when workers leave the establishment, followed by a slow recovery, suggesting their leave is mostly not voluntary. 
While workers with a match duration of more than five years perform best in terms of employment over the whole observation period, they are also the group with the largest gap in wages compared to workers entering incumbents. This result shows again that a longer career within a start-up does not seem to pay off in terms of income and wages.

Additionally, we analyze whether the main reason why workers entering start-ups are less successful on the labor market can be found in the bad economic performance of these establishments. Since many start-ups are failing in their very first years of business (see, e.g., Fackler et al. 2013; Fritsch \& Weyh, 2006; Mueller \& Stegmaier, 2015), workers will oftentimes be forced to search for a new job or-in the worst case-become unemployed. Therefore, we divide the group of workers entering a new establishment into those whose employer survives over a considerable period of time, i.e., at least five or ten years, and those whose employer closes down within the respective time frame. ${ }^{27}$ Figure $4 \mathrm{~b}$ shows the income trajectories for these specific groups of workers after entropy balancing, indicating that indeed individuals who enter a start-up that survives for at least five or ten years, respectively, are performing significantly better than those who joined a start-up which closes down within that time window. Therefore, we also compare the performance of workers entering a surviving start-up with those who initially entered an incumbent establishment, as shown in Fig. 4c. However, our results imply that the gap in income between these two groups still amounts to approximately $€ 2000$ to $€ 3000$ in all periods. ${ }^{28}$ Hence, the

\footnotetext{
27 To define establishment exit, we use information on worker flows provided by Hethey-Maier and Schmieder (2013). Instead of categorizing all establishment identifiers which disappear from the data as closures, this allows us to exclude establishments which continue to operate under a different identifier due to mere administrative changes of the identification number or due to take-overs and restructurings, as well as a small fraction which is defined as "unclear" by Hethey-Maier and Schmieder (2013).

${ }^{28}$ For Britain, Adrjan (2018) also finds that successful startups pay higher wages than unsuccessful young firms. Although his results, in contrast to ours, indicate that workers joining successful start-ups initially earn higher wages than those joining an average incumbent, he finds these differences to disappear over time, with disadvantages arising for workers entering successful start-ups instead of incumbents after five years.
}

difference between workers entering start-ups and incumbents cannot solely be explained by the high failure rate of risky new businesses.

Finally, at least one successful strategy for workers joining a start-up might be to use this establishment as a stepping stone to other, potentially more stable or betterpayed positions. We define workers using the start-up as a stepping stone as those who leave it reasonably early, i.e., within the first five years after entry, and without an imminent threat of firm exit, i.e., at least two years before closure. Moreover, they are required to take up a job at a different establishment within a maximum of 90 days. ${ }^{29}$ We then compare these workers who use the start-up as a stepping stone to a balanced sample of all other individuals entering a newly founded establishment, as presented in Fig. 4d, and find that this indeed seems to be a successful strategy. Workers who quickly leave start-ups for positions in other establishments earn approximately $€ 3000$ more income than the comparison group in year one, the year in which the majority of workers leave the start-up. This gap remains remarkably stable over the subsequent observation period. Nonetheless, when we investigate the difference in yearly income to all workers who instead joined an incumbent in year zero, we find that the latter are still performing significantly better (see Fig. 4e). ${ }^{30}$ Thus, even though our analysis of different subsequent career paths after entering a start-up highlights important heterogeneities, it does not reveal any potential channel or strategy through which workers joining a start-up can catch up with or become even more successful than workers entering an incumbent establishment.

\section{Conclusions}

Although the role of start-ups as employers is often discussed politically and many scholars have analyzed

\footnotetext{
${ }^{29}$ Since we do not observe the reason for changing an employer in our data, allowing only for a short period of frictional unemployment makes it more likely that our definition of stepping stones just captures workers who leave the start-up voluntarily for a more preferable position.

${ }^{30}$ Note that Sorenson et al. (2021) find that using a start-up as a stepping stone might be a successful strategy to catch up with individuals entering an incumbent, if workers are able to subsequently join a large and old establishment. However, their results also indicate that this scenario is highly unlikely due to path dependency in workers' employment relations.
} 
the quantity of jobs created by newly founded firms, the implications of joining a start-up for the individual worker have not been analyzed in depth so far. Therefore, we explore the advantages and disadvantages of entering start-ups instead of incumbent firms, both in terms of remuneration and employment prospects, and investigate whether differences in labor market performance are long-lasting over a worker's subsequent career path. We apply entropy balancing to make both groups of entrants comparable and follow individuals in start-ups and incumbent firms over ten years. Our results imply that workers joining a start-up experience significantly lower income and daily wages, as well as less days in employment and more days of benefit receipt, than similar workers joining an incumbent. These severe drawbacks are persistent over the subsequent ten years after entering the respective establishment and they hold for all groups of workers and types of start-ups analyzed.

Concerning earnings differences between workers entering start-ups and those joining incumbents, the negative differential in entry wages found is in accordance with findings by Nyström and Elvung (2014) for Sweden and Fackler et al. (2019) for Germany but somewhat questions the positive or insignificant wage differentials found in some other studies (e.g. Ouimet \& Zarutskie, 2014 and Kim, 2018). Regarding the development of earnings differences over time, our findings are in line with other current research on by Adrjan (2018) for Great Britain and Sorenson et al. (2021) for Denmark, as both studies find long-run pecuniary disadvantages from entering a newly founded firm. ${ }^{31}$ We go beyond existing research by showing that persistent drawbacks from joining a start-up can also be found in terms of (un) employment prospects. We also provide insights concerning the role of the higher failure risk and the lower employment stability in start-ups as potential explanations for the observed differences in labor market performance (see also Schnabel et al., 2011). Analyzing workers who remain employed with their initial employer and workers who enter successful

\footnotetext{
31 The findings by Adrjan (2018) slightly differ from our main insights, since he finds workers to earn higher wages in startups initially, while long-run disadvantages arise due to higher subsequent wage growth in incumbents.
}

vis-à-vis failing start-ups, we still find substantial drawbacks compared to similar workers entering incumbents. When focusing on workers who use start-up employment as a stepping stone to positions in other establishments, we find that even this strategy does not render workers joining newly founded firms as successful as those entering incumbents.

While our main insights imply long-lasting negative consequences from working at a start-up, some limitations of our analysis must be taken into account when interpreting our results. First and foremost, the various indicators of labor market success investigated in this study do not represent all dimensions of job quality. In particular, our data do not allow us to draw any conclusions concerning job satisfaction. Hence, it is possible that workers in start-ups experience especially high levels of job satisfaction due to, e.g., flatter hierarchies or more autonomy and responsibility (Sauermann, 2018). Focusing on remuneration, one must bear in mind that our data do not include information on non-standard means of financial compensation, such as fringe benefits or firm shares. We argue that this shortcoming should not affect our insights, since fringe benefits do not play an important role in the German labor market due to the scope of social security provision by the state (Schmieder, 2013), and employee share ownership is not very common in Germany and rarely found in small establishments (Bellmann \& Möller, 2016). Moreover, the risky nature of start-ups makes it unlikely that firm shares are regarded as an adequate form of compensation by employees. Another limitation could be that our data do not contain self-employed individuals. We thus cannot observe if some workers who were initially employed at start-ups become entrepreneurs themselves, another potential career path that we are not able to analyze. A final, small caveat when interpreting our results is that we do not observe workers' complete employment biographies after entering the respective establishment. However, we claim that the time span of ten years is long enough to observe whether a convergence process sets in and therefore suffices to make meaningful statements on the longrun effects of entering a start-up. 
Since all our insights point towards significant disadvantages from entering a start-up, the question arises why workers decide to join newly founded firms at all. One reason might be that individuals are just not well informed about the negative consequences of working for a start-up. Although the high likelihood of failure among new firms is a stylized fact that is often discussed both politically and scientifically (e.g., Fackler et al., 2013; Fairlie et al., 2019; Geroski, 1995; Haltiwanger et al., 2013), workers might not be aware of the disadvantages arising even if their employers do not fail. A second potential explanation for workers' decision to enter a new firm could be the different types of work environment. As already mentioned, employment in start-ups is often associated with flat hierarchies, a broader set of tasks assigned to a job, and more responsibility for the individual worker. These factors might compensate workers with strong preferences for such non-monetary job attributes for foregone earnings and worse employment prospects. ${ }^{32}$ Finally, it must be noted that newly founded firms often offer opportunities for workers who face disadvantages at the labor market due to, e.g., their age, foreign nationality, or previous unemployment experience (Coad et al., 2017; Fackler et al., 2019; Nyström, 2012). Put differently, for some groups of workers, the

\footnotetext{
32 An analysis of R\&D employees in the USA by Sauermann (2018) indeed shows that individuals working in start-ups have strong preferences for job attributes such as autonomy and responsibility but place less importance on job security and income.
}

superior alternative of joining an incumbent may simply not be available. From this perspective, working at a start-up can still offer an opportunity for disadvantaged workers who would otherwise be unemployed, especially if they enter start-ups that prosper and survive or if they intend to use the start-up as a stepping stone for (better) positions in other establishments.

In conclusion, since our insights indicate that jobs created by start-ups do not provide workers with the same opportunities for long-run career advancement as those created by incumbents, the role of new firms as job creators should be interpreted cautiously (see also Sorenson et al., 2021). Even though the strong political attention and financial support which start-ups receive in many countries is probably not motivated by the expectation that they create stable high-wage employment, the worker-level perspective taken in our analyses provides some additional support for the skepticism toward start-up subsidization expressed by some authors (e.g., Santarelli \& Vivarelli, 2007; Shane, 2009). 


\section{Appendix}

Table 3 Results of OLS regression of various labor market outcomes in the unbalanced sample

\begin{tabular}{|c|c|c|c|c|c|c|c|c|c|c|c|c|}
\hline \multirow{2}{*}{$\begin{array}{l}\text { Variable } \\
\text { Year } 0\end{array}$} & \multicolumn{3}{|c|}{ (a) Yearly income } & \multicolumn{3}{|c|}{ (b) Average daily full-time earnings } & \multicolumn{3}{|c|}{ (c) Days in employment } & \multicolumn{3}{|c|}{ (d) Days of benefit receipt } \\
\hline & $18,303.73$ & $(21.43)$ & $* * *$ & 79.40 & $(0.06)$ & $* * *$ & 264.69 & $(0.14)$ & $* * *$ & 37.63 & $(0.11)$ & $* * *$ \\
\hline Year 1 & $21,978.38$ & $(23.12)$ & $* * *$ & 83.63 & $(0.06)$ & $* * *$ & 308.11 & $(0.13)$ & $* * *$ & 29.69 & $(0.10)$ & $* * *$ \\
\hline Year 2 & $22,138.95$ & $(24.87)$ & $* * *$ & 86.29 & $(0.07)$ & $* * *$ & 295.00 & $(0.16)$ & $* * *$ & 42.90 & $(0.13)$ & $* * *$ \\
\hline Year 3 & $22,357.43$ & $(25.95)$ & $* * *$ & 87.77 & $(0.08)$ & $* * *$ & 291.94 & $(0.16)$ & $* * *$ & 48.30 & $(0.14)$ & $* * *$ \\
\hline Year 4 & $22,720.79$ & $(26.58)$ & $* * *$ & 89.35 & $(0.08)$ & $* * *$ & 292.26 & $(0.17)$ & $* * *$ & 50.52 & $(0.15)$ & $* * *$ \\
\hline Year 5 & $23,056.27$ & (26.85) & $* * *$ & 90.53 & $(0.08)$ & $* * *$ & 293.62 & $(0.17)$ & $* * *$ & 52.34 & $(0.15)$ & $* * *$ \\
\hline Year 6 & $23,463.79$ & (27.09) & $* * *$ & 91.69 & $(0.08)$ & $* * *$ & 296.27 & $(0.17)$ & $* * *$ & 53.38 & $(0.16)$ & $* * *$ \\
\hline Year 7 & $23,947.89$ & $(27.24)$ & $* * *$ & 92.66 & $(0.08)$ & $* * *$ & 299.75 & $(0.17)$ & $* * *$ & 51.55 & $(0.16)$ & $* * *$ \\
\hline Year 8 & $24,389.72$ & $(27.42)$ & $* * *$ & 94.17 & $(0.08)$ & $* * *$ & 302.51 & $(0.16)$ & $* * *$ & 49.65 & $(0.16)$ & $* * *$ \\
\hline Year 9 & $24,767.74$ & (27.68) & $* * *$ & 95.98 & $(0.08)$ & $* * *$ & 304.06 & $(0.16)$ & $* * *$ & 48.68 & $(0.15)$ & $* * *$ \\
\hline Year 10 & $25,240.97$ & (28.01) & $* * *$ & 98.09 & $(0.08)$ & $* * *$ & 306.10 & $(0.16)$ & $* * *$ & 47.37 & $(0.15)$ & $* * *$ \\
\hline Start-up*year 0 & $-5,454.52$ & (43.38) & $* * *$ & -21.64 & $(0.13)$ & $* * *$ & -10.88 & $(0.36)$ & $* * *$ & 19.78 & $(0.32)$ & $* * *$ \\
\hline Start-up*year 1 & $-7,076.54$ & (46.23) & $* * *$ & -24.34 & $(0.14)$ & $* * *$ & -16.86 & $(0.35)$ & $* * *$ & 16.90 & $(0.30)$ & $* * *$ \\
\hline Start-up*year 2 & $-7,982.83$ & $(50.29)$ & $* * *$ & -24.34 & $(0.16)$ & $* * *$ & -30.05 & $(0.44)$ & $* * *$ & 26.32 & $(0.39)$ & $* * *$ \\
\hline Start-up*year 3 & $-8,201.48$ & $(52.80)$ & $* * *$ & -24.40 & $(0.17)$ & $* * *$ & -31.68 & $(0.47)$ & $* * *$ & 28.49 & $(0.42)$ & $* * *$ \\
\hline Start-up*year 4 & $-8,320.96$ & $(54.50)$ & $* * *$ & -24.85 & $(0.18)$ & $* * *$ & -30.93 & $(0.48)$ & $* * *$ & 29.19 & $(0.44)$ & $* * *$ \\
\hline Start-up*year 5 & $-8,239.11$ & (55.64) & $* * *$ & -24.62 & $(0.18)$ & $* * *$ & -29.12 & $(0.48)$ & $* * *$ & 28.87 & $(0.45)$ & $* * *$ \\
\hline Start-up*year 6 & $-8,193.62$ & $(56.75)$ & $* * *$ & -24.38 & $(0.18)$ & $* * *$ & -28.18 & $(0.49)$ & $* * *$ & 29.72 & $(0.47)$ & $* * *$ \\
\hline Start-up*year 7 & $-8,093.04$ & $(57.80)$ & $* * *$ & -24.08 & $(0.18)$ & $* * *$ & -25.98 & $(0.48)$ & $* * *$ & 29.54 & $(0.48)$ & $* * *$ \\
\hline Start-up*year 8 & $-7,957.13$ & $(58.80)$ & $* * *$ & -23.55 & $(0.19)$ & $* * *$ & -23.19 & $(0.47)$ & $* * *$ & 28.22 & $(0.47)$ & $* * *$ \\
\hline Start-up*year 9 & $-7,885.24$ & $(59.81)$ & $* * *$ & -23.09 & $(0.19)$ & $* * *$ & -21.39 & $(0.47)$ & $* * *$ & 26.94 & $(0.47)$ & $* * *$ \\
\hline Start-up*year 10 & $-7,905.55$ & $(60.84)$ & $* * *$ & -22.72 & $(0.19)$ & $* * *$ & -20.87 & $(0.47)$ & $* * *$ & 26.33 & $(0.47)$ & $* * *$ \\
\hline Number of obs & $7,242,162$ & & & $5,030,629$ & & & $7,242,162$ & & & $7,242,162$ & & \\
\hline $\mathrm{R}^{2}$ & 0.5803 & & & 0.7861 & & & 0.854 & & & 0.1865 & & \\
\hline
\end{tabular}

Sources: Integrated Employment Biographies (IEB); Establishment History Panel (BHP); authors' calculations. Notes: Ordinary least squares regressions. Standard errors (reported in parentheses) are clustered by individual workers. *, **, and *** indicate statistical significance at the 10,5 , and $1 \%$ level, respectively 
Table 4 Results of OLS regression of various labor market outcomes in the balanced sample

\begin{tabular}{|c|c|c|c|c|c|c|c|c|c|c|c|c|}
\hline \multirow{2}{*}{$\begin{array}{l}\text { Variable } \\
\text { Year } 0\end{array}$} & \multicolumn{3}{|c|}{ (a) Yearly income } & \multicolumn{3}{|c|}{$\begin{array}{l}\text { (b) Average daily full-time } \\
\text { earnings }\end{array}$} & \multicolumn{3}{|c|}{ (c) Days in employment } & \multicolumn{3}{|c|}{ (d) Days of benefit receipt } \\
\hline & $15,804.24$ & $(25.59)$ & $* * *$ & 68.93 & $(0.08)$ & $* * *$ & 259.79 & $(0.20)$ & $* * *$ & 52.03 & $(0.19)$ & $* * *$ \\
\hline Year 1 & $18,688.50$ & $(27.44)$ & $* * *$ & 71.99 & $(0.08)$ & $* * *$ & 301.06 & $(0.19)$ & $* * *$ & 41.44 & $(0.18)$ & $* * *$ \\
\hline Year 2 & $18,418.55$ & $(29.75)$ & $* * *$ & 74.67 & $(0.09)$ & $* * *$ & 283.00 & $(0.24)$ & $* * *$ & 57.40 & $(0.22)$ & $* * *$ \\
\hline Year 3 & $18,417.96$ & $(31.04)$ & $* * *$ & 75.94 & $(0.10)$ & $* * *$ & 278.37 & $(0.26)$ & $* * *$ & 64.13 & $(0.24)$ & $* * *$ \\
\hline Year 4 & $18,620.72$ & $(31.85)$ & $* * *$ & 77.10 & $(0.10)$ & $* * *$ & 278.41 & $(0.26)$ & $* * *$ & 66.88 & $(0.25)$ & $* * *$ \\
\hline Year 5 & $18,879.33$ & (32.34) & $* * *$ & 78.15 & $(0.10)$ & $* * *$ & 279.33 & $(0.27)$ & $* * *$ & 68.91 & $(0.26)$ & $* * *$ \\
\hline Year 6 & $19,269.10$ & $(32.81)$ & $* * *$ & 79.37 & $(0.10)$ & $* * *$ & 282.40 & $(0.27)$ & $* * *$ & 70.31 & $(0.27)$ & $* * *$ \\
\hline Year 7 & $19,765.24$ & $(33.21)$ & $* * *$ & 80.31 & $(0.10)$ & $* * *$ & 286.92 & $(0.26)$ & $* * *$ & 68.02 & $(0.27)$ & $* * *$ \\
\hline Year 8 & $20,240.61$ & $(33.52)$ & $* * *$ & 81.89 & $(0.10)$ & $* * *$ & 290.75 & $(0.26)$ & $* * *$ & 65.30 & $(0.27)$ & $* * *$ \\
\hline Year 9 & $20,609.86$ & (33.97) & $* * *$ & 83.82 & $(0.11)$ & $* * *$ & 292.62 & $(0.26)$ & $* * *$ & 63.70 & $(0.27)$ & $* * *$ \\
\hline Year 10 & $21,030.33$ & $(34.44)$ & $* * *$ & 85.93 & $(0.11)$ & $* * *$ & 294.83 & $(0.26)$ & $* * *$ & 61.94 & $(0.27)$ & $* * *$ \\
\hline Start-up*year 0 & $-2,955.03$ & $(45.56)$ & $* * *$ & -11.18 & $(0.14)$ & $* * *$ & -5.98 & $(0.39)$ & $* * *$ & 5.38 & $(0.36)$ & $* * *$ \\
\hline Start-up*year 1 & $-3,786.66$ & $(48.51)$ & $* * *$ & -12.71 & $(0.15)$ & $* * *$ & -9.81 & $(0.38)$ & $* * *$ & 5.15 & $(0.34)$ & $* * *$ \\
\hline Start-up*year 2 & $-4,262.43$ & $(52.84)$ & $* * *$ & -12.72 & $(0.17)$ & $* * *$ & -18.05 & $(0.48)$ & $* * *$ & 11.82 & $(0.43)$ & $* * *$ \\
\hline Start-up*year 3 & $-4,262.00$ & $(55.45)$ & $* * *$ & -12.57 & $(0.18)$ & $* * *$ & -18.11 & $(0.51)$ & $* * *$ & 12.66 & $(0.47)$ & $* * *$ \\
\hline Start-up*year 4 & $-4,220.89$ & $(57.22)$ & $* * *$ & -12.60 & $(0.19)$ & $* * *$ & -17.09 & $(0.52)$ & $* * *$ & 12.82 & $(0.49)$ & $* * *$ \\
\hline Start-up*year 5 & $-4,062.16$ & $(58.45)$ & $* * *$ & -12.24 & $(0.19)$ & $* * *$ & -14.84 & $(0.53)$ & $* * *$ & 12.29 & $(0.50)$ & $* * *$ \\
\hline Start-up*year 6 & $-3,998.93$ & $(59.65)$ & $* * *$ & -12.07 & $(0.19)$ & $* * *$ & -14.32 & $(0.53)$ & $* * *$ & 12.78 & $(0.52)$ & $* * *$ \\
\hline Start-up*year 7 & $-3,910.39$ & $(60.80)$ & $* * *$ & -11.73 & $(0.20)$ & $* * *$ & -13.15 & $(0.52)$ & $* * *$ & 13.07 & $(0.52)$ & $* * *$ \\
\hline Start-up*year 8 & $-3,808.02$ & $(61.84)$ & $* * *$ & -11.27 & $(0.20)$ & $* * *$ & -11.43 & $(0.52)$ & $* * *$ & 12.57 & $(0.52)$ & $* * *$ \\
\hline Start-up*year 9 & $-3,727.36$ & $(62.91)$ & $* * *$ & -10.92 & $(0.20)$ & $* * *$ & -9.96 & $(0.51)$ & $* * *$ & 11.92 & $(0.52)$ & $* * *$ \\
\hline Start-up*year 10 & $-3,694.91$ & $(64.01)$ & $* * *$ & -10.56 & $(0.21)$ & $* * *$ & -9.59 & $(0.51)$ & $* * *$ & 11.75 & $(0.52)$ & $* * *$ \\
\hline Number of obs & $7,242,162$ & & & $5,030,629$ & & & $7,242,162$ & & & $7,242,162$ & & \\
\hline $\mathrm{R}^{2}$ & 0.5381 & & & 0.758 & & & 0.824 & & & 0.238 & & \\
\hline
\end{tabular}

Sources: Integrated Employment Biographies (IEB); Establishment History Panel (BHP); authors' calculations. Notes: Ordinary least squares regressions. Standard errors (reported in parentheses) are clustered by individual workers. *, **, and *** indicate statistical significance at the 10,5 , and $1 \%$ level, respectively 

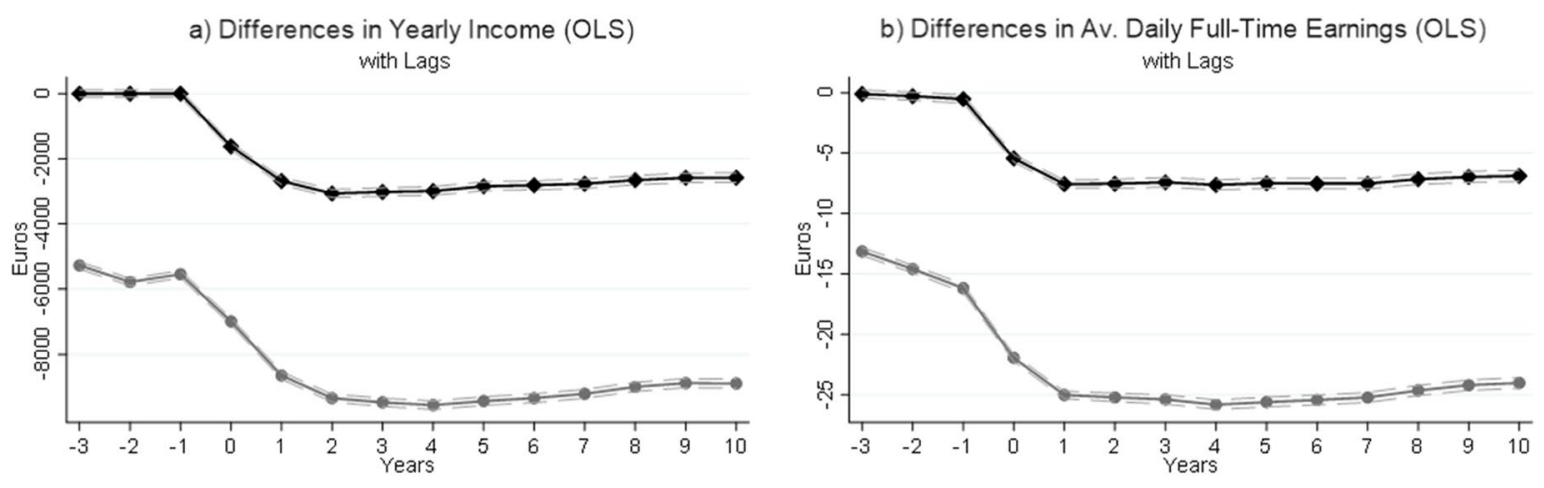

c) Differences in Days in Employment (OLS)

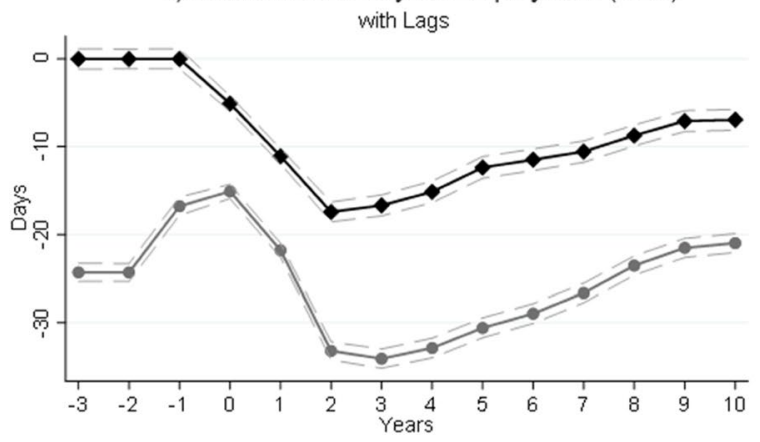

d) Differences in Days of Benefit Receipt (OLS)
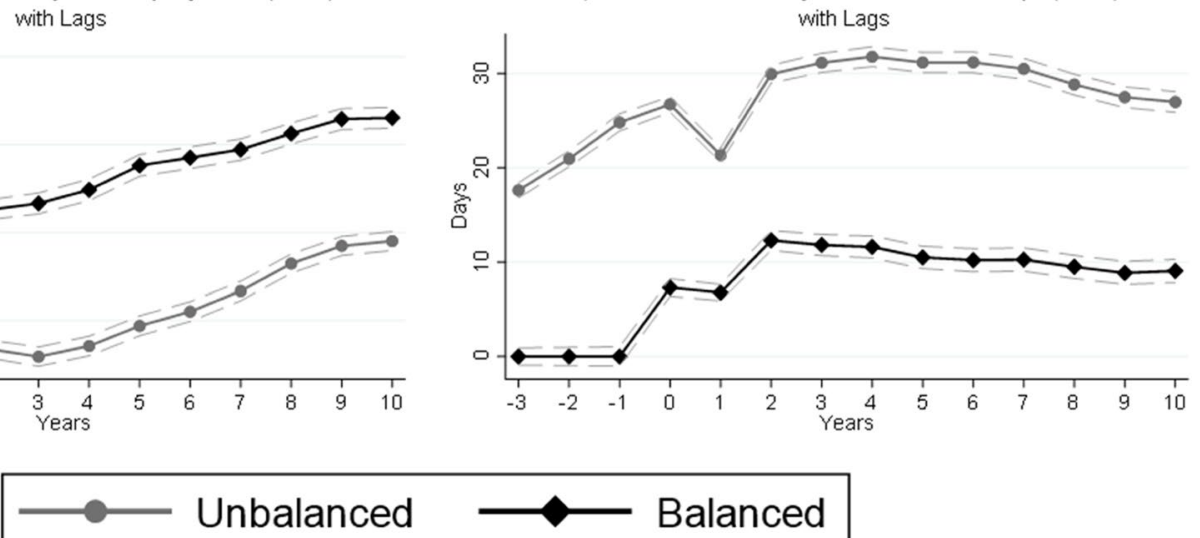

Balanced

Fig. 5 a-d OLS estimates of differences in labor market trajectories between workers entering new and incumbent establishments, including lags of labor market outcomes in the balancing procedure. Sources: Integrated Employment Biographies (IEB); Establishment History Panel (BHP); authors' calculations. Notes: Sample includes only workers entering establishments in the years 2000-2004, excluding agriculture, energy and mining, and the public and nonprofit sectors. The sample comprises individuals of age 18-50, excluding apprentices. Graphs show the OLS estimates of differences in labor market trajectories between workers entering a start-up or an incumbent, the gray dashed lines indicate the $95 \%$ confidence intervals 
a) Differences in Yearly Income (OLS) Only Small Establishments

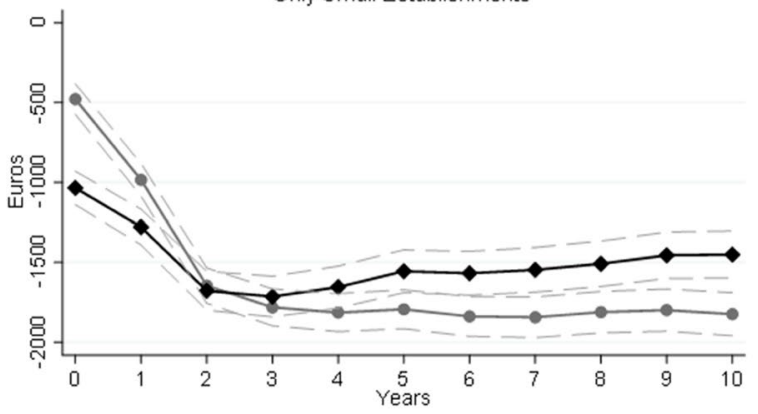

c) Differences in Days in Employment (OLS) Only Small Establishments

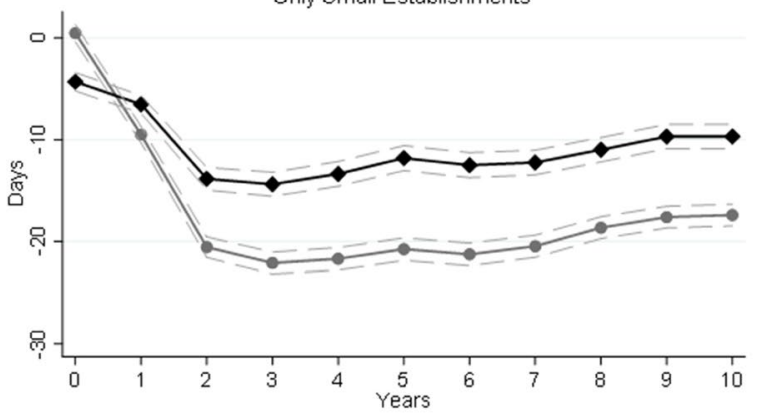

b) Differences in Av. Daily Full-Time Earnings (OLS) Only Small Establishments

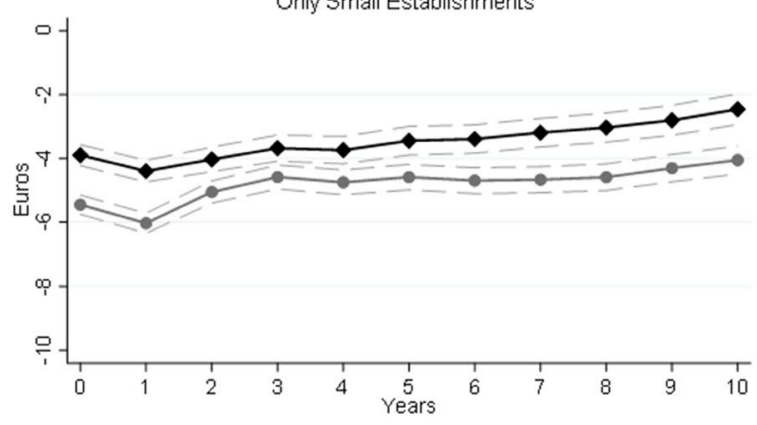

d) Differences in Days of Benefit Receipt (OLS) Only Small Establishments

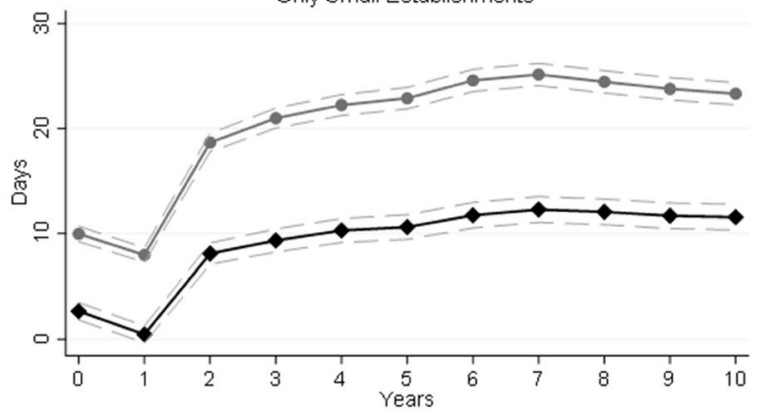

Fig. 6 a-d OLS estimates of differences in labor market trajectories between workers entering new and incumbent establishments, sample restricted to establishments with not more than 20 employees in year zero. Sources: Integrated Employment Biographies (IEB); Establishment History Panel (BHP); authors' calculations. Notes: Sample includes only workers entering establishments with not more than 20 employees in

Acknowledgements We would like to thank Steffen Müller, Joachim Wagner, three reviewers, and an editor of this journal as well as seminar participants at the Halle Institute for Economic Research (IWH), the University of Erlangen-Nürnberg (FAU), the University of Magdeburg, and the IAB for helpful comments and suggestions.

Funding Open Access funding enabled and organized by Projekt DEAL.

Data availability For information regarding data access and/ or the computer programs used for this study, please contact antje.weyh@iab.de.

Open Access This article is licensed under a Creative Commons Attribution 4.0 International License, which permits use, sharing, adaptation, distribution and reproduction in any medium or format, as long as you give appropriate credit to the original author(s) and the source, provide a link to the Creative the years 2000-2004, excluding agriculture, energy and mining, and the public and nonprofit sectors. The sample comprises individuals of age 18-50, excluding apprentices. Graphs show the OLS estimates of differences in labor market trajectories between workers entering a start-up or an incumbent; the gray dashed lines indicate the $95 \%$ confidence intervals

Commons licence, and indicate if changes were made. The images or other third party material in this article are included in the article's Creative Commons licence, unless indicated otherwise in a credit line to the material. If material is not included in the article's Creative Commons licence and your intended use is not permitted by statutory regulation or exceeds the permitted use, you will need to obtain permission directly from the copyright holder. To view a copy of this licence, visit http://creativecommons.org/licenses/by/4.0/.

\section{References}

Adrjan, P. (2018): Risky business? Earnings prospects of employees at young firms, Department of Economics Discussion Paper No. 852, University of Oxford.

Antoni, M., Ganzer, A. \& vom Berge, P. (2016): Sample of integrated labour market biographies (SIAB) 1975-2014, FDZ-Datenreport 04/2016, Nürnberg.

Babina, T., Ma, W., Moser, C., Ouimet, P. \& Zarutskie, R. (2019): Pay, employment, and dynamics of young firms, 
CES Working Paper 19-23, U.S. Census Bureau, Washington, DC. https://doi.org/10.21034/iwp.21

Bellmann, L., \& Möller, I. (2016). Are firms with financial participation of employees better off in a crisis? Evidence from the IAB Establishment Panel Survey. Management Revue, 27, 304-320. https://doi.org/10.1688/mrev-2016Bellmann

Block, J. H., Fisch, C. O., \& van Praag, M. (2018). Quantity and quality of jobs by entrepreneurial firms. Oxford Review of Economic Policy, 34, 565-583. https://doi.org/ 10.1093/oxrep/gry016

Blossfeld, H.-P. (1987). Labor market entry and the sexual segregation of careers in the Federal Republic of Germany. American Journal of Sociology, 93, 89-118. https://doi.org/10.1086/228707

Brand, J. E. (2015). The far-reaching impact of job loss and unemployment. Annual Review of Sociology, 41, 359375. https://doi.org/10.1146/annurev-soc-071913-043237

Brixy, U., Kohaut, S., \& Schnabel, C. (2006). How fast do newly founded firms mature? Empirical analyses on job quality in start-ups. In M. Fritsch \& J. Schmude (Eds.), Entrepreneurship in the region (pp. 95-112). Springer.

Brixy, U., Kohaut, S., \& Schnabel, C. (2007). Do newly founded firms pay lower wages? First evidence from Germany. Small Business Economics, 29, 161-171. https:// doi.org/10.1007/s11187-006-0015-X

Brown, C., \& Medoff, J. L. (2003). Firm age and wages. Journal of Labor Economics, 21, 677-697. https://doi.org/10. 1086/374963

Burton, M. D., Dahl, M. S., \& Sorenson, O. (2018). Do startups pay less? ILR Review, 71, 1179-1200. https://doi.org/ 10.1177/0019793917747240

Coad, A., Nielsen, K., \& Timmermans, B. (2017). My first employee: an empirical investigation. Small Business Economics, 48, 25-45. https://doi.org/10.1007/ s11187-016-9748-3

Criscuolo, C., Gal, P. \& Menon, C. (2014): The dynamics of employment growth: New evidence from 18 countries, OECD Science, Technology, and Industry Policy Papers 14, OECD Publishing. https://doi.org/10.1787/23074957

Ellguth, P., Kohaut, S., \& Möller, I. (2014). The IAB Establishment Panel - Methodological essentials and data quality. Journal for Labour Market Research, 47, 27-41. https:// doi.org/10.1007/s12651-013-0151-0

Fackler, D., Fuchs, M., Hölscher, L., \& Schnabel, C. (2019). Do start-ups provide employment opportunities for disadvantaged workers? ILR Review, 72, 1123-1148. https:// doi.org/10.1177/0019793918814476

Fackler, D., Schnabel, C., \& Wagner, J. (2013). Establishments exits in Germany: the role of size and age. Small Business Economics, 41, 683-700. https://doi.org/10.1007/ s11187-012-9450-z

Fairlie, R. W., Miranda, J., \& Zolas, N. (2019). Measuring job creation, growth, and survival among the universe of start-ups in the United States using a combined start-up panel data set. ILR Review, 72, 1262-1277. https://doi. org/10.1177/0019793919862764

Firpo, S., Fortin, N. M., \& Lemieux, T. (2009). Unconditional quantile regressions. Econometrica, 77, 953-973. https://doi.org/10.3982/ECTA6822

Fritsch, M., \& Weyh, A. (2006). How large are the direct employment effects of new businesses? An empirical investigation for West Germany. Small Business Economics, 27, 245-260. https://doi.org/10.1007/ s11187-006-0005-z

Geroski, P. A. (1995). What do we know about entry? International Journal of Industrial Organization, 13, 421-440. https://doi.org/10.1016/0167-7187(95) 00498-X

Haltiwanger, J. C., Jarmin, R. S., \& Miranda, J. (2013). Who creates jobs? Small versus large versus young. Review of Economics and Statistics, 95, 347-361. https://doi.org/ 10.1162/REST_a_00288

Hainmueller, J. (2012). Entropy balancing for causal effects: A Multivariate reweighting method to produce balanced samples in observational studies. Political Analysis, 20, 25-46. https://doi.org/10.1093/pan/mpr025

Hainmueller, J. \& Xu, Y. (2013): ebalance: A Stata package for entropy balancing. Journal of Statistical Software, 54(7). https://doi.org/10.18637/jss.v054.i07

Hethey-Maier, T., \& Schmieder, J. F. (2013). Does the use of worker flows improve the analysis of establishment turnover? Evidence from German administrative data. Schmollers Jahrbuch, 133, 477-510. https://doi.org/10. 3790/schm.133.4.477

Jovanovic, B. (1982). Selection and the evolution of industry. Econometrica, 50, 649-670. https://doi.org/10.2307/ 1912606

Kim, J. D. (2018). Is there a startup wage premium? Evidence from MIT graduates. Research Policy, 47, 637-649. https://doi.org/10.1016/j.respol.2018.01.010

Kropp, P., \& Schwengler, B. (2011). Abgrenzung von Arbeitsmarktregionen - ein Methodenvorschlag. Raumforschung und Raumordnung, 69, 45-62. https://doi.org/ 10.1007/s 13147-011-0076-4

Mueller, S., \& Stegmaier, J. (2015). Economic failure and the role of plant age and size. Small Business Economics, 44, 621-638. https://doi.org/10.1007/ s11187-014-9616-y

Nyström, K. (2012). Labor mobility and entrepreneurship: Who do new firms employ? In C. Karlsson, B. Johansson, \& R. R. Stough (Eds.), Entrepreneurship, social capital and governance: Directions for the sustainable development and competitiveness of regions (pp. 102114). Edward Elgar Publishing.

Nyström, K., \& Elvung, G. Z. (2014). New firms and labor market entrants: Is there a wage penalty for employment in new firms? Small Business Economics, 43, 399-410. https://doi.org/10.1007/s11187-014-9552-x

Nyström, K. (2021). Working for an entrepreneur: Heaven or hell? Small Business Economics, 56, 919-931. https://doi. org/10.1007/s11187-019-00276-0

Ouimet, P., \& Zarutskie, R. (2014). Who works for startups? The relation between firm age, employee age, and growth. Journal of Financial Economics, 112, 386-407. https://doi.org/ 10.1016/j.jfineco.2014.03.003

Santarelli, E., \& Vivarelli, M. (2007). Entrepreneurship and the process of firms' entry, survival and growth. Industrial and Corporate Change, 16, 455-488. https://doi.org/10.1093/ icc/dtm010

Sauermann, H. (2018). Fire in the belly? Employee motives and innovative performance in start-ups versus established 
firms. Strategic Entrepreneurship Journal, 12, 423-454. https://doi.org/10.1002/sej.1267

Schmieder, J. F. (2013): What causes wage dispersion? Evidence from new firms, Working Paper, Boston University, Available at: https://sites.google.com/site/johannesschmieder/ Schmieder_WagesNewFirms_WorkingPaper.pdf?attredirec $\mathrm{ts}=0 \& \mathrm{~d}=1$. Accessed 4 March 2021.

Schmucker, A., Seth, S., Ludsteck, J., Eberle, J. \& Ganzer, A. (2016): Establishment history panel 1975-2014, FDZ Datenreport 03/2016, Nürnberg.

Schnabel, C., Kohaut, S., \& Brixy, U. (2011). Employment stability in newly founded firms: A matching approach using linked employer-employee data from Germany. Small Business Economics, 36, 85-100. https://doi.org/10.1007/ s11187-009-9188-4
Shane, S. (2009). Why encouraging more people to become entrepreneurs is bad public policy. Small Business Economics, 33, 141-149. https://doi.org/10.1007/s11187-009-9215-5

Sorenson, O., Dahl, M. S., Canales, R., \& Burton, M. D. (2021). Do startup employees earn more in the long run? Organization Science, online first. https://doi.org/10.1287/orsc.2020. 1371

Publisher's note Springer Nature remains neutral with regard to jurisdictional claims in published maps and institutional affiliations. 